\title{
Nanoscale
}

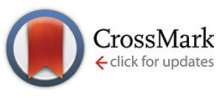

Cite this: Nanoscale, 2016, 8, 5106

Received 29th September 2015 Accepted 25th January 2016

DOI: $10.1039 / c 5 n r 06757 j$

www.rsc.org/nanoscale

\section{Low generation polyamine dendrimers bearing flexible tetraethylene glycol as nanocarriers for plasmids and siRNA $\uparrow$}

\author{
Rishi Sharma, ${ }^{a}$ Issan Zhang, ${ }^{\text {b }}$ Tze Chieh Shiao, ${ }^{a}$ Giovanni M. Pavan, ${ }^{c}$ \\ Dusica Maysinger*b and René Roy*a
}

\begin{abstract}
Low G1 generation polyamine dendrimers built around programmable, flexible, and short tetraethyleneglycol branches were readily prepared in a divergent manner using a combination of orthogonal $\mathrm{AB}_{3}$ or $\mathrm{AB}_{5}$ units and highly efficient chemical transformations based on $\mathrm{Cu}(\mathrm{l})$ catalyzed alkyne-azide cycloaddition (CUAAC) and thiol-ene click reactions. The constructs showed that the G1 polyamines with only twelve and eighteen amine surface groups can successfully deliver siRNA in human cells, with transfection efficiency comparable to that of Lipofectamine $2000 ®$. Measurements of cell viability following transfection of plasmid DNA and siRNA showed that the dendritic polyamines are less cytotoxic than Lipofectamine $2000 \AA$ and are thus preferable for biological applications.
\end{abstract}

\section{Introduction}

Dendrimers are hyperbranched macromolecules which are synthesized in an algorithmic step-by-step pattern by joining repetitive building blocks around a central core. ${ }^{1-3}$ Unlike traditional polymers, dendrimers can be synthesized in a more controlled tailor-made fashion where manipulations can be performed at any growth phase to tune their chemical and biophysical properties. Due to their unique precisely controlled three dimensional molecular architectures, dendrimers have made their way in diverse fields of science such as drug delivery, catalysis, molecular sensing, imaging, gene therapy, light harvesting, and diagnosis. ${ }^{4-8}$ Amine-terminated dendrimers such as polyamidoamine (PAMAM) ${ }^{9}$ poly(propyleneimine) $(\mathrm{PPI}){ }^{10}$ polyethyleneimine (PEI), ${ }^{11}$ PETIM,${ }^{12}$ carbosilane,${ }^{13}$ phosphorus, ${ }^{14}$ dendrimersomes and nanomicelles, ${ }^{15}$ and polyesters $^{16}$ have shown high potential in a wide range of biomedical applications and for gene delivery in particular. Regardless of their numerous relevant biological applications, inherent cytotoxicity remains a key bottleneck for polyamine

\footnotetext{
${ }^{a}$ Pharmaqam, Department of Chemistry, Université du Québec à Montréal, P.O. Box 8888, Succ. Centre-ville, Montréal, Canada H3C 3P8. E-mail: roy.rene@uqam.ca; Fax: +1-514-987-4054; Tel: +1-514-987-3000 ext 2546

${ }^{b}$ Department of Pharmacology and Therapeutics, McGill University, 3655 Promenade Sir-William-Osler, Montreal, Quebec H3G 1Y6, Canada.

E-mail: dusica.maysinger@mcgill.ca; Fax: +1 514-398-6690; Tel: +1-514-398-1264 ${ }^{c}$ Department of Innovative Technologies, University of Applied Sciences and Arts of Southern Switzerland, Galleria 2, 6928 Manno, Switzerland

$\dagger$ Electronic supplementary information (ESI) available. See DOI: 10.1039/ c5nr06757j
}

dendrimer applications, which limits their clinical usefulness. ${ }^{17,18}$ The exact mechanism behind the toxicity associated with polyamine scaffolds is believed to be due to electrostatic interactions between the cationic dendrimers and the anionic cell membranes, which can be disrupted upon contact.

Significant research has been recently done to develop strategies which can reduce the cytotoxicity of polycationic dendrimers. Surface modifications are the most commonly used methods which can decrease dendrimers' cytotoxicity by neutralizing their highly positive surface charge. Partial acetylation, fluorination, glycation, and conjugation of biocompatible materials (e.g. polyethylene glycol and cyclodextrins) to the surface of dendrimers have shown promise in reducing cytotoxicity, but unfortunately, these modifications also decrease the efficiency of the dendrimers, particularly for applications where numerous charges are important., 19-21 Conjugation of polyethylene glycol (PEG) chains with hyperbranched polymers and dendrimers is an extensively used approach to improve the cytotoxicity profile of these scaffolds by decreasing the electrostatic interactions between cell membranes and dendrimers. ${ }^{22}$ Moreover, PEGylated biomacromolecules are approved by the FDA and attachment of PEG to dendrimers provides several other pharmacological advantages, such as increased blood circulation time, lower/nonimmunogenicity, and improved bio-distribution. ${ }^{23-26}$ Furthermore, the inclusion of PEG chains in the backbone of dendrimers also enhances water solubility, which in turn improves bioavailability and pharmacokinetic profiles.

During the past decade, significant progress has been made in the field of dendrimer syntheses, indicating that many of 
the drawbacks, such as high cost, multi-step synthesis, low reproducibility and complex purification procedures, can be partly resolved. ${ }^{27-29}$ Despite these developments, facile and efficient strategies are still deficient to construct biocompatible polyamine systems. In most studies, the focus is restricted to surface derivatization of commercially available polyamine dendrimers with biocompatible materials to improve their cytotoxicity profile. Due to a gap between demand and efficient synthesis, there is an urgent need to develop innovative, rapid and cost economical synthetic routes to facilitate the access of amine terminating hyperbranched macromolecules. We report herein a highly efficient, elegant, and short synthesis of a library of low generation polyamine dendrimers consisting of conformationally adaptable tetraethylene glycol chains embedded in the backbone. Furthermore, we demonstrate the use of two low generation dendrimers for the intracellular delivery of plasmid DNA and siRNA in two human cell lines, HEK 293 human embryonic kidney cells and U251N human glioblastoma cells, showing lower cytotoxic effects compared to a commercial standard, Lipofectamine $2000 ®$.

\section{Experimental}

\subsection{Materials and methods}

All reactions in organic medium were performed in standard oven dried glassware under an inert atmosphere of nitrogen using freshly distilled solvents. Solvents and reagents were deoxygenated when necessary by purging with nitrogen. All reagents were used as supplied without prior purification unless otherwise stated, and obtained from Sigma-Aldrich Chemical Co. Ltd. Reactions were monitored by analytical thin-layer chromatography (TLC) using silica gel 60 F254 precoated plates (E. Merck) and compounds were visualized with a $254 \mathrm{~nm}$ UV lamp, a mixture of iodine/silica gel and/or a mixture of ceric ammonium molybdate solution $(100 \mathrm{~mL}$ $\left.\mathrm{H}_{2} \mathrm{SO}_{4}, 900 \mathrm{~mL} \mathrm{H} \mathrm{H}_{2} \mathrm{O}, 25 \mathrm{~g}\left(\mathrm{NH}_{4}\right)_{6} \mathrm{Mo}_{7} \mathrm{O}_{24} \mathrm{H}_{2} \mathrm{O}, 10 \mathrm{~g} \mathrm{Ce}\left(\mathrm{SO}_{4}\right)_{2}\right)$ and subsequent spots development by gentle warming with a heat-gun. Purifications were performed by silica gel flash

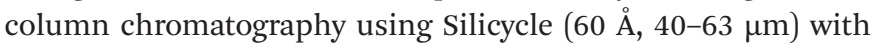
the indicated eluent.

${ }^{1} \mathrm{H}$ NMR and ${ }^{13} \mathrm{C}$ NMR spectra were recorded at 300 or $600 \mathrm{MHz}$ and at 75 or $150 \mathrm{MHz}$ on a Bruker spectrometer $(300 \mathrm{MHz})$ and on a Varian spectrometer $(600 \mathrm{MHz})$, respectively. All NMR spectra were recorded at $25{ }^{\circ} \mathrm{C}$ in indicated deuterated solvents. Proton and carbon chemical shifts $(\delta)$ are reported in ppm and coupling constants $(J)$ are reported in hertz $(\mathrm{Hz})$. The resonance multiplicity in the ${ }^{1} \mathrm{H}$ NMR spectra is described as "s" (singlet), "d" (doublet), "t" (triplet), "quint" (quintuplet) and "m" (multiplet) and broad resonances are indicated by "br". Residual protic solvents of $\operatorname{CDCl}_{3}\left({ }^{1} \mathrm{H}\right.$, $\delta 7.27 \mathrm{ppm} ;{ }^{13} \mathrm{C}, \delta 77.0 \mathrm{ppm}$ (central resonance of the triplet)), $\mathrm{D}_{2} \mathrm{O}\left({ }^{1} \mathrm{H}, \delta 4.79 \mathrm{ppm}\right.$ and $30.9 \mathrm{ppm}$ for $\mathrm{CH}_{3}$ of acetone for ${ }^{13} \mathrm{C}$ spectra), and MeOD $\left({ }^{1} \mathrm{H}, \delta 3.31 \mathrm{ppm}\right.$ and $\left.{ }^{13} \mathrm{C}, \delta 49.0 \mathrm{ppm}\right)$ were used for chemical shift calibration. 2D homonuclear correlation ${ }^{1} \mathrm{H}-{ }^{1} \mathrm{H}$ COSY experiments were used to confirm NMR peak assignments. Gel Permeation Chromatography (GPC) was performed using water as the eluent, at $40{ }^{\circ} \mathrm{C}$ with a $1 \mathrm{~mL}$ $\min ^{-1}$ flow rate on a Viscotek VE 2001 GPCmax (SEC System) with Wyatt DSP/Dawn EOS and refractive index RI/LS system as detectors. 2 PLGel mixed B LS $(10 \mu \mathrm{m}, 300 \times 7.5 \mathrm{~mm})$ and LS-MALLS detection with performances verified with polystyrene $100 \mathrm{kDa}$ and $2000 \mathrm{kDa}$ were used to determine the number-average molecular weight $\left(M_{\mathrm{n}}\right)$ and polydispersity index $\left(M_{\mathrm{w}} / M_{\mathrm{n}}\right)$. Calculations were performed with Zimm Plot (model). Fourier transform infrared (FTIR) spectra were obtained with Thermo-Scientific, Nicolet model 6700 equipped with ATR. The absorptions are given in wavenumbers $\left(\mathrm{cm}^{-1}\right)$. Accurate mass measurements (HRMS) were performed on a LC-MSD-TOF instrument from Agilent Technologies in positive electrospray mode. Either protonated molecular ions $[\mathrm{M}+n \mathrm{H}]^{n+}$ or adducts $[\mathrm{M}+n \mathrm{X}]^{n+}\left(\mathrm{X}=\mathrm{Na}, \mathrm{K}, \mathrm{NH}_{4}\right)$ were used for empirical formula confirmation. MALDI-TOF experiments were performed on an Autoflex III from Brucker Smarteam in linear positive mode (Mass Spectrometry Laboratory (McGill University)) to afford adducts $[\mathrm{M}+n \mathrm{X}]^{n+}(\mathrm{X}=\mathrm{Na}, \mathrm{K}$ or Li).

\subsection{Synthetic protocols and characterization}

2.2.1. General procedure for CUAAC click reaction (Procedure A). An acetylene-terminated compound (1 eq.) and an azido derivative ( 2 eq. per acetylene) were suspended in a 1:1 mixture of $\mathrm{THF}$ and water in a $5 \mathrm{~mL}$ microwave vial equipped with a magnetic stir bar. To this were added $\mathrm{CuSO}_{4} \cdot 5 \mathrm{H}_{2} \mathrm{O}$ (0.5 eq. per acetylene) and sodium ascorbate $(0.5$ eq. per acetylene) dissolved in the minimum amount of water. The vial was tightly capped and reaction was irradiated in a microwave at $50{ }^{\circ} \mathrm{C}$ for $6 \mathrm{~h}$. Reaction completion was monitored with the help of TLC and on completion the reaction mixture was diluted with ethyl acetate. The organic layer was washed with a saturated solution of EDTA (3-4 times) and dried with anhydrous sodium sulphate followed by concentration in vacuo. This procedure has been extensively demonstrated to remove trace amount of copper salt ${ }^{30}$ down to the level of $<12 \mathrm{ppm}^{31}$ Silica gel column chromatography was performed to isolate the desired compounds.

2.2.2. General procedure for thiol-ene click reaction (Procedure B). An allylated dendrimer (1 eq.), cysteamine hydrochloride (5 eq. per site) and AIBN (10 mol\% per site) were placed in a microwave vial followed by the addition of $1 \mathrm{~mL}$ dry methanol. The reaction mixture was purged with nitrogen and the vial was tightly capped. The reaction mixture was irradiated in a microwave synthesizer initiator from Biotage set for 5-8 h (depending upon the number of allyl groups) at $90{ }^{\circ} \mathrm{C}$. Upon completion, methanol was evaporated and the reaction mixture was washed with diethyl ether to remove excess low molecular weight reagents. The reaction mixture was then dissolved in a minimum amount of water and transferred in a dialysis bag of $1 \mathrm{kDa}$ cut off membrane. The dialysis was performed against pure water for 12 hours and water was changed 5-6 times in between. The solution was lyophilised to afford the final products. 
2.2.3. Synthesis of compound 9. Compound 8 (100 mg, $0.347 \mathrm{mmol}$ ), azide 7 (951 mg, $2 \mathrm{mmol}, 6 \mathrm{eq}$.), sodium ascorbate $(137 \mathrm{mg}, 0.694 \mathrm{mmol})$ and copper sulphate $(172 \mathrm{mg}$, $0.694 \mathrm{mmol}$ ) were reacted according to Procedure A to give compound 9 which was further purified using silica gel column chromatography. The pure product was isolated using $4 \% \mathrm{MeOH}$ in DCM as the eluent in $72 \%$ yield.

${ }^{1} \mathrm{H}$ NMR (300 MHz, $\left.\mathrm{CDCl}_{3}\right): \delta 7.70(\mathrm{~s}, 4 \mathrm{H}), 5.94-5.82(\mathrm{~m}$, $12 \mathrm{H}$ ), 5.36-5.06 (m, 24H), 4.54 (d, $J=4.7 \mathrm{~Hz}, 16 \mathrm{H}), 3.98-3.92$ $(\mathrm{m}, 24 \mathrm{H}), 3.88(\mathrm{t}, J=5.3 \mathrm{~Hz}, 8 \mathrm{H}), 3.69-3.52(\mathrm{~m}, 50 \mathrm{H}), 3.49-3.42$ $(\mathrm{m}, 38 \mathrm{H})$.

${ }^{13} \mathrm{C}$ NMR $\left(75 \mathrm{MHz}, \mathrm{CDCl}_{3}\right): \delta 144.9,135.08,123.4,115.9$, 77.2, 72.0, 70.84, 70.4, 70.3, 70.1, 69.3, 69.1, 64.7, 49.9, 45.2, 45.1 .

HRMS (ESI ${ }^{+}$-TOF) $m / z$ : calculated for $\mathrm{C}_{105} \mathrm{H}_{176} \mathrm{~N}_{12} \mathrm{O}_{32}$ : 2118.58, found: $1060.13[\mathrm{M}+2 \mathrm{H}]^{+2}, 2119.25[\mathrm{M}+\mathrm{H}]^{+}$.

IR $\left(\mathrm{cm}^{-1}\right): 3705,3680,3078,2865,1725,1645,1478,1453$, 1420, 1349, 1249, 1196, 1083, 1033, 1004, 920, 832, 774.

2.2.4. Synthesis of compound 3. Perallylated dendrimer 9 (180 mg, $0.085 \mathrm{mmol}$ ), AIBN (17 mg, $0.102 \mathrm{mmol}, 1.2 \mathrm{eq}$.) and cysteamine hydrochloride $(577 \mathrm{mg}, 5.1 \mathrm{mmol}, 60 \mathrm{eq}$.) were treated according to Procedure $\mathrm{B}$ for $5 \mathrm{~h}$ to give compound 3 in $75 \%$ yield.

${ }^{1} \mathrm{H}$ NMR (300 MHz, D $\left.2 \mathrm{O}\right): \delta 8.01(\mathrm{~s}, 4 \mathrm{H}), 4.67-4.48(\mathrm{~m}, 16 \mathrm{H})$, $3.94(\mathrm{~s}, 10 \mathrm{H}), 3.70-3.50(\mathrm{~m}, 85 \mathrm{H}), 3.41(\mathrm{~s}, 40 \mathrm{H}), 3.21(\mathrm{t}, J=6.7$ $\mathrm{Hz}, 24 \mathrm{H}), 2.84(\mathrm{t}, J=6.7 \mathrm{~Hz}, 24 \mathrm{H}), 2.64(\mathrm{t}, J=7.1 \mathrm{~Hz}, 24 \mathrm{H}), 1.85$ (t, $J=12 \mathrm{~Hz}, 24 \mathrm{H})$.

${ }^{13} \mathrm{C}$ NMR (151 MHz, $\left.\mathrm{D}_{2} \mathrm{O}\right): \delta$ 144.8, 125.9, 76.3, 71.2, 70.5, $70.4,70.3,70.2,70.1,69.8,69.4,68.8,64.3,50.6,39.0,28.9$, 28.8, 28.0.

IR $\left(\mathrm{cm}^{-1}\right): 3396,2864,1608,1460,1089,940$.

(MALDI-TOF) $m / z$ : calculated for $\mathrm{C}_{129} \mathrm{H}_{260} \mathrm{~N}_{24} \mathrm{O}_{32} \mathrm{~S}_{12}$ : 3041.61, found: $3042.61[\mathrm{M}+\mathrm{H}]^{+}$.

2.2.5. Synthesis of compound 11. Hexapropargylated core 10 (50 mg, $0.104 \mathrm{mmol}$ ), azide 7 (341 mg, $0.746 \mathrm{mmol}, 7.2$ eq.), sodium ascorbate (62 $\mathrm{mg}, 0.311 \mathrm{mmol})$ and copper sulphate (78 mg, $0.311 \mathrm{mmol}$ ) were reacted according to Procedure A to give compound $\mathbf{1 1}$ which was further purified with the help of silica gel column chromatography. The pure product was isolated using $4 \% \mathrm{MeOH}$ in DCM as the eluent in $72 \%$ yield.

${ }^{1} \mathrm{H}$ NMR (300 MHz, $\left.\mathrm{CDCl}_{3}\right): \delta 7.70(\mathrm{~s}, 6 \mathrm{H}), 5.96-5.80(\mathrm{~m}$, $18 \mathrm{H}), 5.18$ (ddd, $J=13.8,11.7,1.5 \mathrm{~Hz}, 36 \mathrm{H}), 4.51(\mathrm{~s}, 24 \mathrm{H}), 3.94$ (d, $J=5.3 \mathrm{~Hz}, 36 \mathrm{H}), 3.87(\mathrm{t}, J=5.3 \mathrm{~Hz}, 12 \mathrm{H}), 3.65-3.53(\mathrm{~m}$, $76 \mathrm{H}), 3.48-3.41$ (m, 60H).

${ }^{13} \mathrm{C} \quad \mathrm{NMR}\left(75 \mathrm{MHz}, \mathrm{CDCl}_{3}\right): \quad \delta$ 145.0, 135.1, 123.5, 116.0, 77.2, 72.1, 70.9, 70.5, 70.4, 70, 69.9, 69.3, 69.2, 64.8, 49.9, 45.3.

MALDI-TOF $m / z$ : calculated for $\mathrm{C}_{160} \mathrm{H}_{268} \mathrm{~N}_{18} \mathrm{O}_{49}$ : 3227.9311 , found, $3250.741[\mathrm{M}+\mathrm{Na}]^{+}$.

IR ( $\left.\mathrm{cm}^{-1}\right): 3499,3079,2866,1725,1645,1477,1350,1290$, 1083, 993, 921, 833.

2.2.6. Synthesis of compound 4. Perallylated dendrimer 11 (250 mg, $0.077 \mathrm{mmol}$ ), AIBN (38 mg, $0.232 \mathrm{mmol}, 3$ eq.) and cysteamine hydrochloride ( $525 \mathrm{mg}, 4.6 \mathrm{mmol}, 60 \mathrm{eq}$.) were reacted according to Procedure B for $5 \mathrm{~h}$ to give compound 4 .
${ }^{1} \mathrm{H}$ NMR $\left(300 \mathrm{MHz}, \mathrm{D}_{2} \mathrm{O}\right): \delta 7.99(\mathrm{~s}, 6 \mathrm{H}), 4.63-4.45(\mathrm{~m}, 28 \mathrm{H})$, 3.92 (br s, 14H), 3.71-3.49 (m, 128H), 3.47-3.33 (m, 67H), 3.20 $(\mathrm{t}, J=6.7 \mathrm{~Hz}, 43 \mathrm{H}), 2.83(\mathrm{t}, J=6.7 \mathrm{~Hz}, 36 \mathrm{H}), 2.62(\mathrm{t}, J=7.2 \mathrm{~Hz}$, $36 \mathrm{H}), 1.91-1.77$ (m, 36H).

${ }^{13} \mathrm{C}$ NMR (75 MHz, $\left.\mathrm{D}_{2} \mathrm{O}\right): \delta 144.79,125.6,76.1,71.1,70.3$, 70.2 , 70.1, 70.0, 69.6, 69.4, 69.2, 69.1, 64.4, 50.5, 45.9, 45.3, 43.9, 39.5, 38.9, 28.9, 28.6, 27.9, 27.5, 18.1 .

MALDI-TOF $m / z$ : calculated for: $\mathrm{C}_{196} \mathrm{H}_{394} \mathrm{~N}_{36} \mathrm{O}_{49} \mathrm{~S}_{18}$ : 4616.61, found, $4639.993[\mathrm{M}+\mathrm{Na}]^{+}$.

IR ( $\left.\mathrm{cm}^{-1}\right):$ 3403, 2865, 1606, 1459, 1369, 1087, 939.

2.2.7. Synthesis of compound 13. Hexapropargylated core 10 (20 mg, $0.0414 \mathrm{mmol}$ ), pentaallylated azide 12 (325 mg, $0.496 \mathrm{mmol}, 12 \mathrm{eq}$.), sodium ascorbate (25 mg, $0.124 \mathrm{mmol}$, 3 eq.) and copper sulphate (31 mg, $0.124 \mathrm{mmol}, 3$ eq.) were reacted according to Procedure A to give compound 13 which was further purified using silica gel column chromatography. The pure product was isolated using $4 \% \mathrm{MeOH}$ in DCM as the eluent in $79 \%$ yield.

${ }^{1} \mathrm{H}$ NMR $\left(300 \mathrm{MHz}, \mathrm{CDCl}_{3}\right): \delta 7.70(\mathrm{~s}, 6 \mathrm{H}), 5.96-5.80(\mathrm{~m}$, $30 \mathrm{H}), 5.31-5.08(\mathrm{~m}, 60 \mathrm{H}), 4.52(\mathrm{~s}, 22 \mathrm{H}), 3.98-3.85(\mathrm{~m}, 74 \mathrm{H})$, $3.66-3.52$ (m, 76H), 3.48-3.35 (m, 108H).

${ }^{13} \mathrm{C}$ NMR $\left(151 \mathrm{MHz}, \mathrm{CDCl}_{3}\right): \delta 145.0,135.2,123.5,116.0$, $72.2,70.9,70.5,70.4,70.3,70.2,70.1,69.9,69.8,69.4,69.3$, $64.8,49.9,45.5,29.6$.

HRMS (ESI ${ }^{+}$-TOF) $m / z$ : calculated for $\mathrm{C}_{226} \mathrm{H}_{376} \mathrm{~N}_{18} \mathrm{O}_{67}$ : 4414.6568, found: $4436.64[\mathrm{M}+\mathrm{Na}]^{+}$.

IR $\left(\mathrm{cm}^{-1}\right): 3694,3680,3078,2865,1728,1645,1477,1454$, 1420, 1349, 1302, 1083, 1032, 1003, 919.

2.2.8. Synthesis of compound 5. Compound $13(150 \mathrm{mg}$, $0.046 \mathrm{mmol}$ ), AIBN (38 mg, $0.46 \mathrm{mmol}, 6 \mathrm{eq}$.) and cysteamine hydrochloride (781 mg, $6.9 \mathrm{mmol}, 150$ eq.) were reacted according to Procedure $\mathrm{B}$ to give compound $\mathbf{5}$.

${ }^{1} \mathrm{H}$ NMR (300 MHz, $\left.\mathrm{D}_{2} \mathrm{O}\right): \delta 8.00(\mathrm{~s}, 6 \mathrm{H}), 4.54(\mathrm{~d}, J=23.2 \mathrm{~Hz}$, $28 \mathrm{H}), 3.93(\mathrm{~s}, 16 \mathrm{H}), 3.67-3.52(\mathrm{~m}, 154 \mathrm{H}), 3.49-3.39(\mathrm{~m}, 81 \mathrm{H})$, $3.21(\mathrm{t}, J=6.7 \mathrm{~Hz}, 66 \mathrm{H}), 2.85(\mathrm{t}, J=6.7 \mathrm{~Hz}, 60 \mathrm{H}), 2.64(\mathrm{t}, J=7.0$ $\mathrm{Hz}, 60 \mathrm{H}), 1.95-1.76(\mathrm{~m}, 60 \mathrm{H})$.

${ }^{13} \mathrm{C}$ NMR (151 MHz, $\left.\mathrm{D}_{2} \mathrm{O}\right): \delta 144.3,125.2,75.8,70.7,70.5$, $70.1,69.8,69.7,69.6,69.4,68.9,68.6,63.9,50.0,48.9,45.4$, 45.3, 39.2, 39.1, 38.5, 28.5, 28.3, 28.0, 27.9, 27.5, 27.3, 17.8.

HRMS $\left(\mathrm{ESI}^{+}\right.$-TOF) $\mathrm{m} / \mathrm{z}$ : calculated for $\mathrm{C}_{286} \mathrm{H}_{586} \mathrm{~N}_{48} \mathrm{O}_{67} \mathrm{~S}_{30}$ : 6725.55, found: 6728.55 .

IR $\left(\mathrm{cm}^{-1}\right):$ 3400, 2862, 1608, 1484, 1458, 1091, 1032, 939.

2.2.9. Synthesis of compound 15. Hexapropargylated $\mathrm{N}_{3} \mathrm{P}_{3}$ core 14 (10 mg, $0.0098 \mathrm{mmol}$ ), azide 12 (202 mg, 00784, 8 eq.), sodium ascorbate (15 mg, $0.059 \mathrm{mmol}, 6 \mathrm{eq}$.) and copper sulphate (12 mg, $0.0592 \mathrm{mmol}, 6$ eq.) were reacted according to Procedure A to give compound $\mathbf{1 5}$ which was further purified using silica gel column chromatography. The pure product was isolated using $4 \% \mathrm{MeOH}$ in DCM as the eluent in $67 \%$ yield.

${ }^{1} \mathrm{H}$ NMR $\left(300 \mathrm{MHz}, \mathrm{CDCl}_{3}\right): \delta 7.84(\mathrm{~s}, 6 \mathrm{H}), 6.81(\mathrm{q}, J=9.1 \mathrm{~Hz}$, $24 \mathrm{H}), 5.94-5.79(\mathrm{~m}, 30 \mathrm{H}), 5.29-5.18(\mathrm{~m}, 30 \mathrm{H}), 5.16-5.08(\mathrm{~m}$, $40 \mathrm{H}), 4.53(\mathrm{~s}, 12 \mathrm{H}), 3.97-3.83(\mathrm{~m}, 74 \mathrm{H}), 3.65-3.52(\mathrm{~m}, 74 \mathrm{H})$, $3.42(\mathrm{t}, J=4.3 \mathrm{~Hz}, 74 \mathrm{H}), 3.38(\mathrm{~d}, J=2.3 \mathrm{~Hz}, 20 \mathrm{H})$.

${ }^{13} \mathrm{C} \mathrm{NMR}\left(75 \mathrm{MHz}, \mathrm{CDCl}_{3}\right): \delta 155.2,144.5,143.6,135.2,124$, $121.8,116,115.2,72.2,71,70.6,70.5,70.4,70.3,70.2,70,69.5$, $69.3,69.2,62.2,50.2,45.5,29.6$. 
${ }^{31} \mathrm{P}$ NMR $\left(122 \mathrm{MHz}, \mathrm{CDCl}_{3}\right) \delta 9.76(\mathrm{~s})$.

MALDI-TOF $m / z$ : calculated for $\mathrm{C}_{252} \mathrm{H}_{384} \mathrm{~N}_{21} \mathrm{O}_{72} \mathrm{P}_{3}$ : 4949.62, found, 4949.08 .

IR $\left(\mathrm{cm}^{-1}\right): 3074,3006,2866,1646,1501,1476,1420,1350$, 1265, 1189, 1172, 1089, 1033, 1008, 952, 923, 890, 834.

2.2.10. Synthesis of compound 6. Perallylated dendrimer 15 (120 mg, $0.024 \mathrm{mmol}$ ), AIBN (24 mg, $0.145 \mathrm{mmol}, 6$ eq.) and cysteamine hydrochloride (657 mg, $5.8 \mathrm{mmol}, 240$ eq.) were reacted according to Procedure B to give compound $\mathbf{6}$ in $85 \%$ yield.

${ }^{1} \mathrm{H}$ NMR (300 MHz, $\left.\mathrm{D}_{2} \mathrm{O}\right): \delta 8.17(\mathrm{~s}, 6 \mathrm{H}), 6.96-6.80(\mathrm{~m}, 24 \mathrm{H})$, $5.23(\mathrm{~s}, 12 \mathrm{H}), 4.61(\mathrm{~s}, 12 \mathrm{H}), 3.92(\mathrm{~s}, 16 \mathrm{H}), 3.65-3.27(\mathrm{~m}, 224 \mathrm{H})$, $3.20(\mathrm{t}, J=6.7 \mathrm{~Hz}, 72 \mathrm{H}), 2.84(\mathrm{t}, J=6.6 \mathrm{~Hz}, 64 \mathrm{H}), 2.60(\mathrm{~d}, J=$ $6.5 \mathrm{~Hz}, 60 \mathrm{H}), 1.83(\mathrm{~s}, 60 \mathrm{H})$.

${ }^{13} \mathrm{C}$ NMR (151 MHz, $\left.\mathrm{D}_{2} \mathrm{O}\right): \delta$ 157.5, 146.5, 145.4, 127.9, 124.2, 118.3, 78.1, 74.7, 73.0, 72.3, 72.1, 72.0, 71.9, 71.5, 71.1, $66.8,66.1,65.5,64.0,52.5,47.7,47.6,45.7,42.4,41.5,41.4$, $40.8,40.0,37.1,36.4,35.6,35.2,30.5,29.8,29.5,28.3,28.2$, 28.1, 24.6, 20.8, 20.1.

${ }^{31} \mathrm{P}$ NMR (122 MHz, MeOD): $\delta 8.73$ (s).

HRMS (ESI ${ }^{+}$-TOF) $m / z$ : calculated for $\mathrm{C}_{312} \mathrm{H}_{594} \mathrm{~N}_{51} \mathrm{O}_{72} \mathrm{P}_{3} \mathrm{~S}_{30}$ : 7260.5221 , found: 7260.4336 .

IR $\left(\mathrm{cm}^{-1}\right): 3388,2919,2864,1608,1500,1461,1261,1188$, 1171, 1093, 1033, 951, 885, 833.

2.2.11. Synthesis of FITC-conjugated dendrimer 16. Fluorescein isothiocyanate $(1.7 \mathrm{mg}, 4.4 \mu \mathrm{mol}, 1.0$ equiv.) and compound 4 ( $23 \mathrm{mg}, 4.4 \mu \mathrm{mol}, 1.0$ equiv.) were stirred together in a mixture of aqueous sodium bicarbonate $(900 \mu \mathrm{L}, 100 \mathrm{mM}$; $\mathrm{pH} 8.5)$ and acetonitrile $(100 \mu \mathrm{L})$ at room temperature for $12 \mathrm{~h}$. The solvent was removed under pressure and the final FITCconjugated dendrimer 16 was purified by dialysis.

${ }^{1} \mathrm{H}$ NMR (600 MHz, D $\left.\mathrm{D}_{2} \mathrm{O}\right): \delta 8.00(\mathrm{~d}, J=27.2 \mathrm{~Hz}, 6 \mathrm{H})$, 7.33-6.58 (m, FITC-H), 4.66-4.42 (m, 28H), 3.99-3.87 (m, 14H), $3.73-3.49$ (m, 128H), 3.49-3.30 (m, 70H), 3.23 (dd, $J=14.1,7.0$ $\mathrm{Hz}, 45 \mathrm{H}), 2.90-2.70$ (m, 36H), 2.71-2.55 (m, 36H), 1.94-1.75 $(\mathrm{m}, 36 \mathrm{H})$.

${ }^{13} \mathrm{C}$ NMR (151 MHz, $\left.\mathrm{D}_{2} \mathrm{O}\right): \delta$ 144.4, 125.3, 75.8, 70.7, 70.1, $69.8,69.4,69.0,63.9,50.1,45.1,39.2,39.1,38.5,30.1,30.0$, 29.9, 29.8, 29.7, 28.5, 28.3, 27.5.

HRMS $\left(\mathrm{ESI}^{+}\right.$-TOF) $\mathrm{m} / z$ : calculated for $\mathrm{C}_{217} \mathrm{H}_{405} \mathrm{~N}_{37} \mathrm{O}_{54} \mathrm{~S}_{19}$ : 5005.9881, found: $1001.5046[\mathrm{M}+5 \mathrm{H}]^{5+}$.

\subsection{Cell culture and treatment}

HEK 293, U251N, MCF-7 and HepG2 cell lines were originally obtained from the American Type Culture Collection. HEK 293, U251N and MCF-7 cells were maintained in Dulbecco's Modified Eagle's Medium (DMEM, Invitrogen) containing 10\% (v/v) fetal bovine serum (FBS, Invitrogen), 2 mM L-glutamine, $100 \mathrm{IU} \mathrm{mL} \mathrm{mL}^{-1}$ penicillin, $100 \mu \mathrm{g} \mathrm{mL}^{-1}$ streptomycin (Invitrogen), and $1 \%$ non-essential amino acids. HepG2 cells were maintained in Minimum Essential Medium (Invitrogen) supplemented in the same manner. Cells were cultured at $37{ }^{\circ} \mathrm{C}$ with $5 \% \mathrm{CO}_{2}$. Cells were seeded at 10000 cells per well in 96well tissue culture plates (Corning) and cultured for $24 \mathrm{~h}$ prior to treatments. For the MTT assay, cells were treated with increasing concentrations of dendrimers ( $1 \mathrm{nM}, 10 \mathrm{nM}, 50$
nM, $100 \mathrm{nM}, 500 \mathrm{nM}, 1 \mu \mathrm{M}, 5 \mu \mathrm{M}, 10 \mu \mathrm{M}$ ) for $24 \mathrm{~h}$. Dendrimers were solubilized in purified water. For cell viability assays, U251N cells were treated with $0.94-23.56 \mu \mathrm{M}$ of 3 , $0.62-15.57 \mu \mathrm{M}$ of 4 and $0.47-9.46 \mu \mathrm{M}$ of 5 for $24 \mathrm{~h}$.

\subsection{MTT assay}

Following treatment with cationic dendrimers $3\left(\mathrm{G} 1-12 \mathrm{NH}_{2}\right)$ and $4\left(\mathrm{G} 1-18 \mathrm{NH}_{2}\right)$ at different concentrations and up to $24 \mathrm{~h}$, the culture medium was removed and replaced with serumdeprived DMEM containing thiazolyl blue tetrazolium (MTT, $5 \mathrm{mg} \mathrm{mL}{ }^{-1}$, Sigma-Aldrich). Cells were incubated at $37^{\circ} \mathrm{C}$ for 30 minutes, after which the medium was removed, and dimethyl sulfoxide (DMSO, $100 \mu \mathrm{L}$, Sigma-Aldrich) was added to dissolve the formazan crystals. Colorimetric measurements were made at $595 \mathrm{~nm}$ using a microplate reader (Benchmark, Bio-Rad).

\subsection{Hoechst 33342 labeling}

Following treatment, cell nuclei were labeled with Hoechst 33324 (10 $\mathrm{M}, 10 \mathrm{~min}$, Sigma-Aldrich). The Operetta highthroughput imaging system (Perkin Elmer) was used for cell counting. Five fields were imaged per well. Image analysis was performed by using the Columbus Image Analysis Software (Perkin Elmer).

\subsection{Organelle labeling}

U251N cells were seeded on glass cover slips (Thermo Fisher Scientific) at 10000 cells per cover slip and cultured for $24 \mathrm{~h}$. The labeling of the endoplasmic reticulum (ER) and the Golgi was performed using Cell Light ER-RFP (Thermo Fisher Scientific) and Cell Light Golgi-RFP (Thermo Fisher Scientific), respectively. Cells were transduced when seeded following the manufacturer's recommendations for 10000 cells and using a particle per cell (PPC) coefficient of 50. The following day, transduced cells were treated with $1 \mu \mathrm{M}$ of FITC-labeled dendrimer 16 for $24 \mathrm{~h}$. Cell nuclei were labeled with Hoechst $33342(10 \mu \mathrm{M}, 10 \mathrm{~min})$, then live imaging was performed using a fluorescence microscope (Leica). For nucleus, mitochondrion and lysosome labeling, cells treated with FITC-labeled dendrimers $(1 \mu \mathrm{M}, 24 \mathrm{~h})$ were incubated with Hoechst $33342(10 \mu \mathrm{M}$, 10 min), MitoTracker Deep Red (100 nM, 3 min, Thermo Fisher Scientific) and LysoTracker Red (500 nM, 3 min, Thermo Fisher Scientific), respectively. Cells were then washed in sterile phosphate buffered saline and imaged under a fluorescence microscope.

\subsection{Transfection of plasmid DNA}

HEK 293 cells were seeded at 10000 cells per well in 96-well tissue culture plates (Sarstedt) and cultured for $24 \mathrm{~h}$. The medium was then renewed without antibiotics, and transfection complexes were added. Transfection complexes were prepared by mixing equal volumes $(100 \mu \mathrm{L})$ of dendrimers and eGFP-encoding plasmids dissolved in Opti-MEM (Invitrogen). The final concentration of eGFP plasmid per well was $0.5 \mu \mathrm{g}$. The dendrimers were added at increasing concentrations, following dendrimer to plasmid DNA charge ratios of $0.8,1,2,5$, 
6,8 , and 10 . The charge ratios were calculated based on the number of positive charges found on the surface groups of the polyamine dendrimers and the number of negative charges of DNA. Transfection complexes were allowed to equilibrate for 15 minutes before they were added to cell cultures, where they were kept for $24 \mathrm{~h}$. Cell nuclei were labeled using Hoechst 33342 (10 $\mu \mathrm{M}, 10 \mathrm{~min})$. Cells were then imaged using the Operetta high-throughput imaging system, and image analysis was performed using Columbus. The transfection efficiencies were calculated from the number of cells expressing eGFP as a proportion of the total number of cells labeled with Hoechst 33342. Lipofectamine $2000 \AA$ (Invitrogen) was included as a commercial comparator. Its use at a ratio of 1 corresponds to the concentration recommended by the manufacturer $(0.5 \mu \mathrm{L}$ of transfection reagent per well).

\subsection{Transfection of Cy3-labeled anti-HSP70 siRNA}

U251N cells were seeded at 10000 cells per well in 96-well cell culture plates and cultured for $24 \mathrm{~h}$. The medium was then renewed without serum or antibiotics, and transfection complexes were added. Transfection complexes were prepared by mixing equal volumes $(100 \mu \mathrm{L})$ of dendrimer and Cy3-labeled anti-HSP70 siRNA (Ambion) dissolved in Opti-MEM. The final concentration of siRNA per well was $10 \mathrm{nM}$. The dendrimers were added at increasing concentrations, following charge ratios (dendrimer to siRNA) of $0.8,1,5,10,15,20,30,40$ and 50. Transfection complexes were left to equilibrate for $15 \mathrm{~min}$, after which they were added to cell cultures and kept for $24 \mathrm{~h}$. Cell nuclei were labeled with Hoechst 33342 and cells were imaged using Operetta. Image analysis was performed using Columbus. Lipofectamine $2000 \AA$ was used following the manufacturer's recommendations $(0.5 \mu \mathrm{L}$ per well). Transfection efficiencies were calculated from the number of cells with intracellular fluorescence above the average of that of nontransfected control cells, as a proportion of the total number of cells (labeled with Hoechst 33342). Non-transfected control cells thus have approximately $50 \%$ of cells with background fluorescence above that of its own average. Negative controls of the eGFP plasmid DNA alone and dendrimer vectors alone in HEK 293 cells are provided in the ESI Fig. S53. $\uparrow$ Negative controls of the siRNA alone and dendrimer vectors alone in U251N cells are provided in ESI Fig. S54. $\dagger$

\subsection{Western blot expression of HSP70}

U251N glioblastoma cells were seeded at $1 \times 10^{6}$ cells per $10 \mathrm{~cm}$ culture plate and cultured for $24 \mathrm{~h}$. The media were replaced by serum-deprived media, and cells were treated with heat-shock protein (HSP70) small interfering RNA (siRNA) (10 $\mathrm{nM}$ ) alone, siRNA bound by dendrimers G1-12 and G1-18 at a charge ratio of 1 to 20 (siRNA to dendrimer), or dendrimers alone for $48 \mathrm{~h}$. Untreated controls were included. Cells were collected in lysis buffer and cell lysates ran in SDS-PAGE (10\%) gels. Proteins were transferred by western blotting to a PVDF membrane overnight. Blocking was achieved using 5\% nonfatty milk in TBS-T. Rabbit monoclonal antibodies against HSP70 (1/1000, Enzo Life Sciences) and mouse monoclonal antibodies against $\beta$-actin (1/5000, Sigma Aldrich) were used for $3 \mathrm{~h}$. Goat anti-rabbit and anti-mouse secondary antibodies (Bio-Rad) were used (1/1000) for $1 \mathrm{~h}$. Chemiluminescence detection was achieved using the SuperSignal West Pico (Thermo Fisher) substrate. HSP70 was detected as a single band at $70 \mathrm{kDa}$. $\beta$-Actin was detected at $42 \mathrm{kDa}$.

\subsection{Statistics}

Independent experiments were performed at least three times. Each treatment was included in three (transfections) or six samples (cytotoxicity assays). All data are expressed as mean \pm SEM values. Statistical significance was calculated using oneway ANOVA and the Student's $t$-test. The Bonferroni correction was applied for multiple comparisons.

\subsection{Computational methods}

The interaction between dendrimer $\mathbf{5}$ and a model of nucleic acid has been modeled and simulated according to a validated procedure used previously for the simulation of similar systems. ${ }^{32,33}$ The entire simulation work was conducted using the AMBER 12 software. $^{34}$ The molecular model for 5 has been parameterized with the "general AMBER force field (GAFF)". 35 As for the nucleic acid, a model of 21 bp Firefly Luciferase (GL3) siRNA was used as described in similar studies. ${ }^{32,33}$

First, dendrimer 5 was immersed in a periodic box containing explicit TIP3P water molecules ${ }^{36}$ and $\mathrm{Cl}^{-}$counterions were added for charge neutralization (at neutral $\mathrm{pH}$ the terminal amines of $\mathbf{5}$ were assumed to be positively charged, for a total dendrimer charge of $+30 e$ ). The system has been preliminarily minimized, and thermalized to reach the experimental temperature of $25^{\circ} \mathrm{C}(298 \mathrm{~K})$. Then, dendrimer 5 has been equilibrated through $100 \mathrm{~ns}$ of $\mathrm{MD}$ simulations under periodic boundary NPT conditions (constant $N$ : number of atoms, $P$ : pressure and $T$ : temperature during the run) at $25^{\circ} \mathrm{C}$ of temperature and 1 atm of pressure. This provided an equilibrated conformation for dendrimer 5 in the solvent, which was then placed in close proximity of the siRNA model. The dendrimersiRNA complex was re-solvated, and underwent the same simulation phases described above providing an equilibrated configuration of the binding between the nucleotide and $\mathbf{5}$ reported in Fig. 5. All equilibration MD runs used a time step of 2 femtoseconds, the Langevin thermostat, a $8 \AA$ cutoff, the particle mesh Ewald ${ }^{37}$ (PME) for long-range electrostatics, and the SHAKE algorithm to treat bonds involving hydrogen atoms. $^{38}$

\section{Results and discussion}

Generation 1 (G1) dendrimers (3-6) (Scheme 1) having twelve to thirty amine peripheral end groups were built in a divergent manner using a combination of orthogonal $\mathrm{AB}_{3}$ or $\mathrm{AB}_{5}$ hypermonomers ${ }^{28}$ and highly efficient chemical transformations based on $\mathrm{Cu}(\mathrm{I})$ catalyzed alkyne-azide cycloaddition $(\mathrm{CUAAC})^{39,40}$ and thiol-ene click reactions. ${ }^{41-44}$ Both of these chemical reactions are nowadays considered as cornerstones 


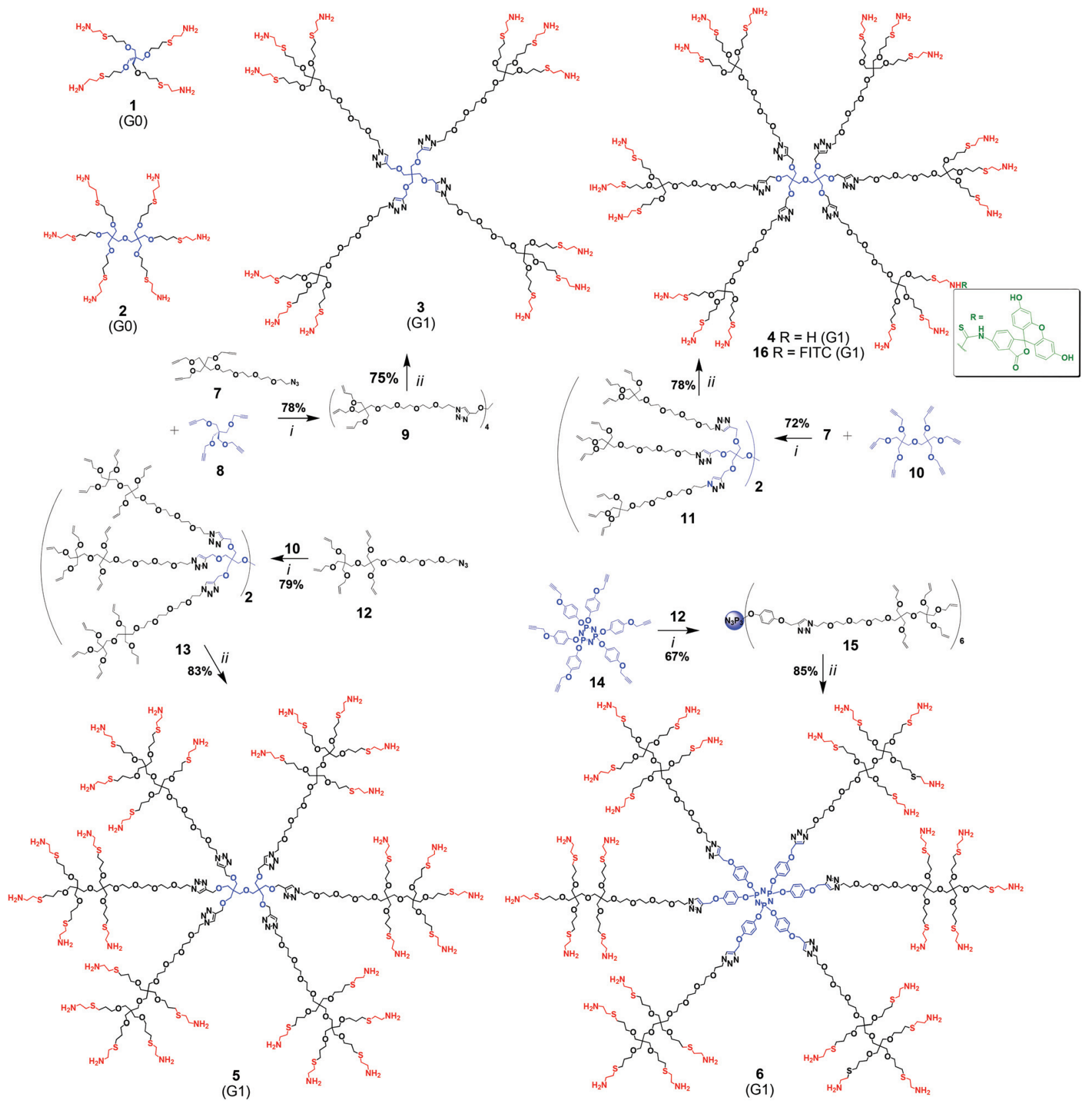

Scheme 1 Synthesis of G1 polyamine dendrimers 3-6 bearing 4, 6, 12, 18, and 30 terminal amine groups. Reagents and conditions: (i) $\mathrm{CuSO}_{4} \cdot 5 \mathrm{H}_{2} \mathrm{O}$, sodium ascorbate, THF : $\mathrm{H}_{2} \mathrm{O}, 50{ }^{\circ} \mathrm{C}$, microwave, $6 \mathrm{~h}$., (ii) $\mathrm{AlBN}, \mathrm{MeOH}$, microwave, $80{ }^{\circ} \mathrm{C}, 6 \mathrm{~h}$.

in the field of polymer and dendrimer synthesis due to their remarkably robust nature, orthogonality, high yields, minimum side products, and tolerance to a wide variety of functional groups and solvents. ${ }^{45}$

The syntheses were successfully achieved up to 30 surface amine groups at only the G1 stage in two steps, whereas in the case of most widely studied commercially available polyamine dendrimers like PAMAM and PPI, a comparable number of end groups (32) can only be achieved at G3 and G4, respectively, and requires 6 to 8 synthetic steps. In contrast to the majority of the reports where PEGylation was performed on the peripheral amines, ${ }^{46}$ tetraethyleneglycol (TEG) units were incorporated into the backbone of the dendrimers to retain the effect of surface amines and simultaneously make the dendrimers water soluble, flexible, and biocompatible. The synthetic protocol is atom economical and highly efficient, does not require protection/deprotection steps and thus, offers important new perspectives in the quest for a fast, simple, and inexpensive synthesis of amine-terminated dendrimers.

The G1 polyamine dendrimers (1-6) illustrated in Scheme 1 , consisting of $4,6,12,18$, and $30-\mathrm{NH}_{2}$ end groups, have been synthesized divergently around pentaerythritol, 
dipentaerythritol or aromatic cyclotriphosphazene cores. ${ }^{47}$ The selection of pentaerythritol cores was based on literature findings which revealed that PAMAM dendrimers around pentaerythritol cores showed less cytotoxicity compared to the parent ones. $^{48,49}$ The syntheses of G0 dendrimers 1 and 2 were achieved using the literature procedure previously reported by our group. ${ }^{44,47}$ For the construction of dendrimer 3, containing twelve amine functionalities, tris-allylated pentaerythritol ether and its TEG azide derivative $7^{28}$ were coupled to tetrakispropargylated pentaerythritol $\mathbf{8}^{47}$ using microwave-promoted CUAAC click reactions under standard reaction conditions $\left(\mathrm{CuSO}_{4} \cdot 5 \mathrm{H}_{2} \mathrm{O}, \mathrm{Na}\right.$ ascorbate in $\left.\mathrm{THF} / \mathrm{H}_{2} \mathrm{O}\right)$ to afford $\mathrm{G} 1$ dendrimer 9 harboring twelve peripheral allyl groups in $78 \%$ yield.

Detailed ${ }^{1} \mathrm{H}$ NMR spectroscopy analysis confirmed complete transformation of reactions showing sharp and symmetrical singlets for triazole protons appearing at $\delta 7.70 \mathrm{ppm}$ and allyl signals at $\delta 5.90-5.06 \mathrm{ppm}$. During our attempts, we found that the microwave irradiation promoted the reaction rate and helped in the completion of reaction within $6 \mathrm{~h}$, while the same reaction, when performed under similar conditions without microwave treatments, took overnight to be completed. Moreover, thin layer chromatography (TLC) also confirmed the cleaner reaction under microwave conditions whereas multiple spots were observed in the reaction without it. Thermal thiol-ene click was performed on perallylated dendrimer 9 by the addition of commercially available cysteamine hydrochloride in the presence of azobisisobutyronitrile (AIBN) as a radical initiator under microwave irradiation to afford polyamine dendrimer 3 with twelve exposed surface amine groups in $75 \%$ yield. No column chromatography purifications were required for this step and the dendrimer was easily purified by washing the reaction mixture with diethyl ether several times followed by dialysis against water (1.0 kDa cut-off). Complete disappearance of alkene signals in the ${ }^{1} \mathrm{H}$ NMR spectra coupled to the fact that sharp signals were observed clearly indicated the presence of a pure product together with total thiol addition and lack of copper traces.

A similar strategy was used for the synthesis of eighteen amine-terminated dendrimer $\mathbf{4}$ around the dense hexa-propargylated dipentaerythritol core $10{ }^{50}$ CUAAC click reaction was performed on the core $\mathbf{1 0}$ and triallyl ether TEG azide 7 using the above mentioned click reaction conditions to provide dendrimer $\mathbf{1 1}$ bearing 18 allyl functions in quantitative yield. It was followed by thermal thiol-ene click reaction of $\mathbf{1 1}$ with cysteamine hydrochloride to afford dendrimer 4 decorated with eighteen surface amines in $78 \%$ yield. Dendrimer 4 was easily purified by a similar non-chromatographic method described above. Fig. 1 illustrates the ${ }^{1} \mathrm{H}$ NMR spectra for the complete reaction sequences for dendrimer 4 showing the respective signals for all the protons. Starting from spectrum A, the triplet at $\delta 2.42(\mathrm{ppm})$ corresponding to propargyl protons disappeared completely after the azide-alkyne click

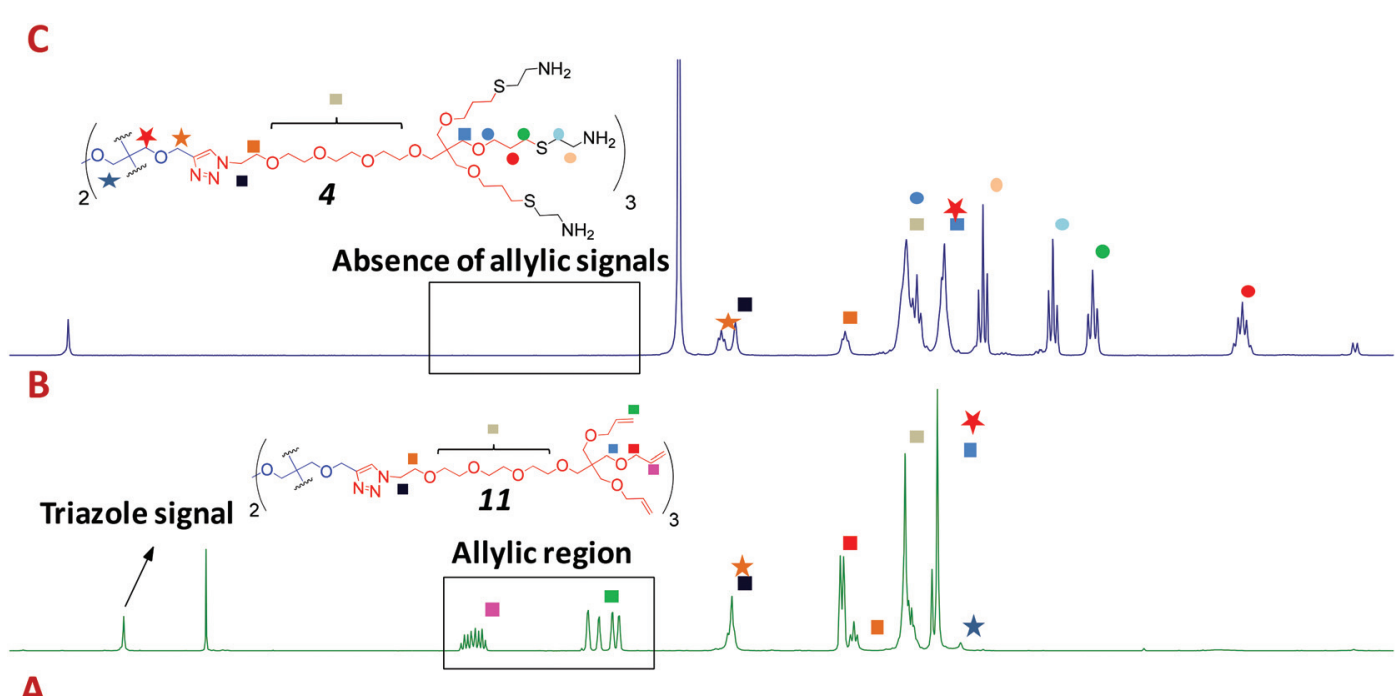

A

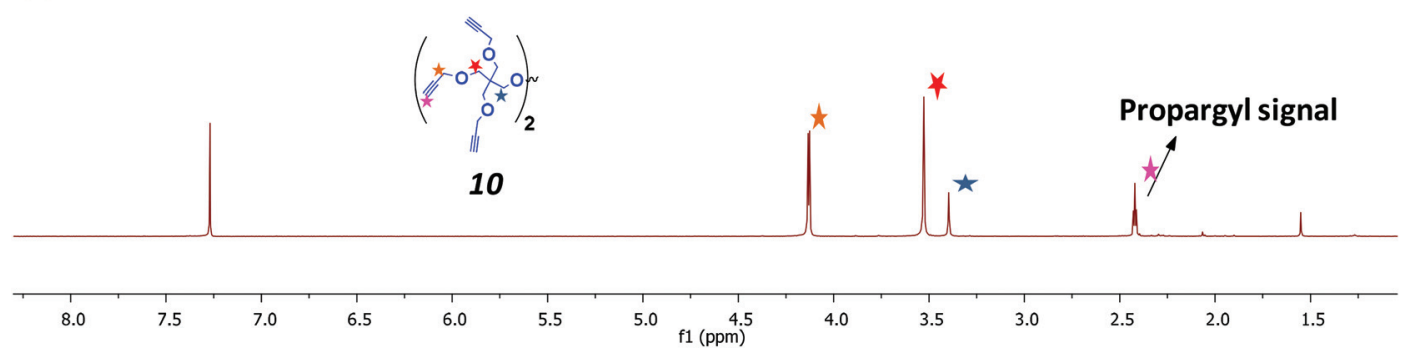

Fig. 1 Comparison of ${ }^{1} \mathrm{H}$ NMR spectra ( $\mathrm{A}$ and $\mathrm{B}$ in $\mathrm{CDCl}_{3}$ and $\mathrm{C}$ in $\mathrm{D}_{2} \mathrm{O}$ ) of 10,11 , and 4 with the appearance/disappearance of characteristic signals towards the construction of G1-18- $\mathrm{NH}_{2}$ dendrimer (4). 
conjugation, with the simultaneous appearance of allyl signals at $\delta$ 5.96-5.18 ppm. After the final thiol-ene step, alkene signals completely disappeared (spectrum B), ensuring complete derivatization. MALDI-TOF mass spectrometry (MS) also supported the formation of the final product 4, showing a mass peak at 4638.99 corresponding to the sodium adduct.

The synthesis of dendrimer $\mathbf{5}$ with thirty amine functions was accomplished by first conducting a CUAAC click reaction between the orthogonal $\mathrm{AB}_{5}$ hypermonomer 12 and the hexapropargylated dipentaerythritol core $\mathbf{1 0}$ using the same synthetic protocol as described above to provide dendrimer $\mathbf{1 3}$ with thirty allyl terminal groups in $79 \%$ yield. MALDI-TOF MS of 13 showed the expected [M+Na] peak at $m / z$ 4436.64. Subsequent thiol-ene click reaction was performed on 13 with cysteamine hydrochloride to produce dendrimer $\mathbf{5}$ with 30 amine groups at the periphery in $83 \%$ yield. A rigid aromatic hexapropargylated cyclotriphosphazene core $14^{47}$ was also chosen for the synthesis of our next dendrimer $\mathbf{6}$, which has a similar number of peripheral amines. The synthesis was carried out by applying the same sequence of reactions, i.e. CUAAC/TEC. CUAAC ligation between 14 and $\mathrm{AB}_{5}$ monomer 12 generated dendrimer 5 having thirty allyl moieties in $67 \%$
A

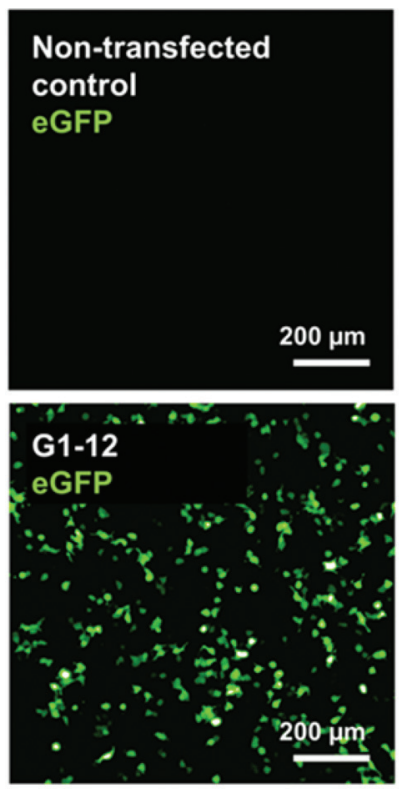

B

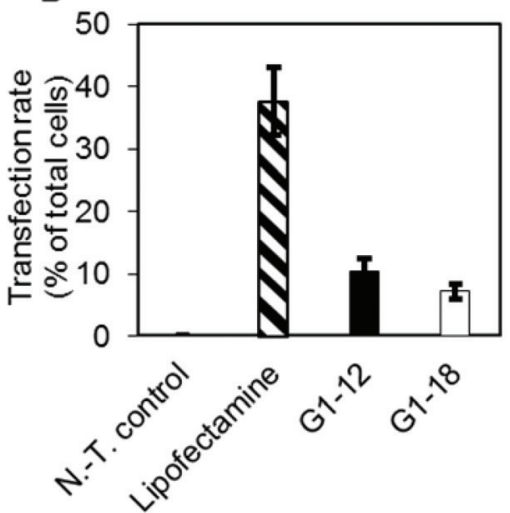

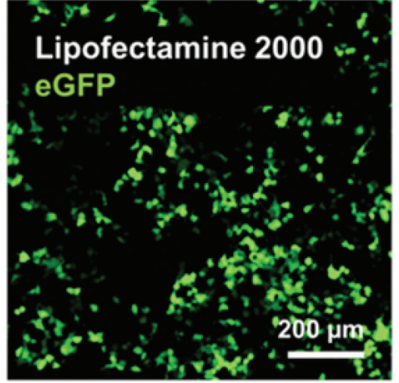

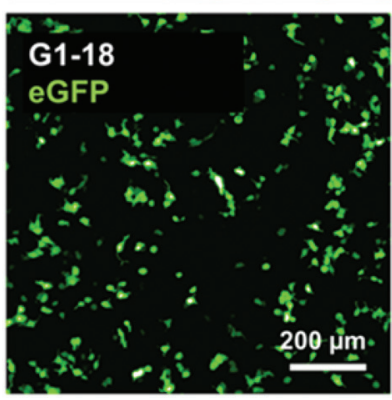

C

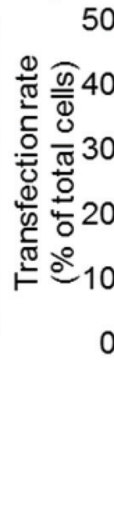

D
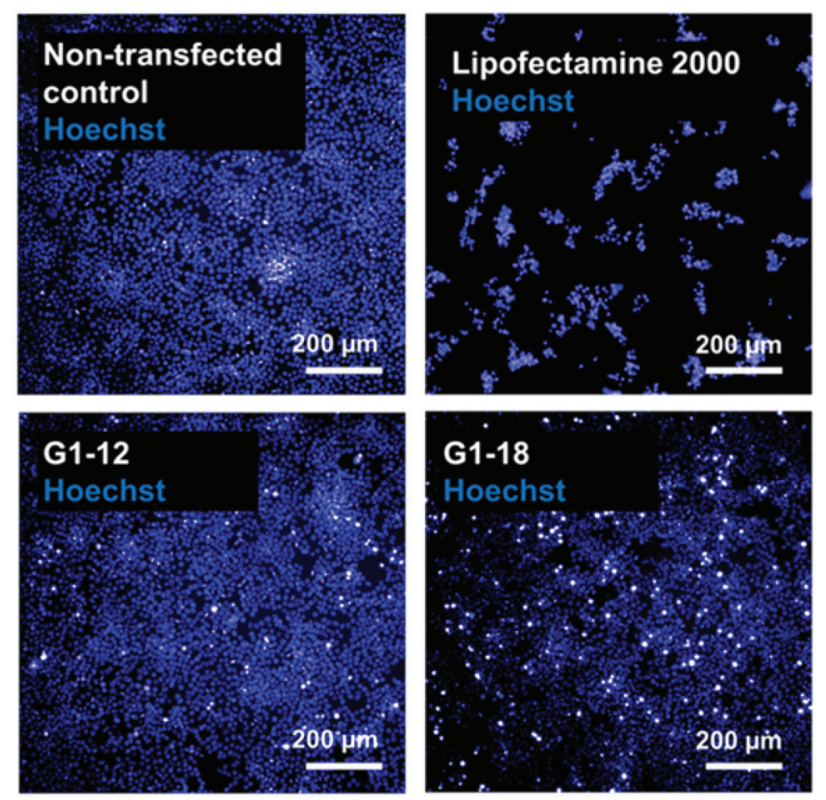

E

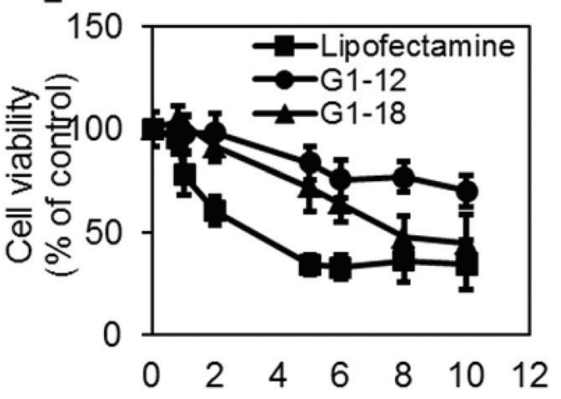

Transfection agent vs pDNA ratio

Transfection agent vs pDNA ratio

Fig. 2 HEK 293 human embryonic kidney cells transfected with eGFP plasmid DNA (pDNA) using 3 (G1-12) and 4 (G1-18) polyamine dendrimers. (A) Micrographs of transfected HEK 293 cells show cells expressing eGFP fluorescence in the cytoplasm. Cells non-transfected or transfected with Lipofectamine $2000 \AA$ were included as controls. (B) Peak transfection efficiencies of HEK 293 cells using Lipofectamine $2000 \AA 3$ or 4 . Transfection efficiencies were calculated as the proportion of total cells (labeled with Hoechst 33342) which express eGFP. Shown are mean percentage values \pm SEM from at least three independent experiments. (C) Transfection efficiency of HEK 293 cells using Lipofectamine $2000 \circledast 3$ or 4 at increasing transfection agent to pDNA charge ratios. Lipofectamine $2000 \AA$ at a ratio of 1 is used at the concentration recommended by the manufacturer. Transfection efficiencies were calculated as in (B). Shown are mean percentage values \pm SEM from at least three independent experiments. (D) Micrographs of HEK 293 cells transfected as in (A). Cell nuclei were labeled with Hoechst 33342 and imaged using a high-throughput fluorescence microscope. (E) HEK 293 cell viability following transfection as in (C). Lipofectamine $2000 \AA$ at a ratio of 1 is used at the concentration recommended by the manufacturer. Shown are mean percentage values \pm SEM as compared to untreated controls from at least three independent experiments. 
yield. The reaction was monitored easily with the help of TLC and ${ }^{1} \mathrm{H}$ NMR, which clearly showed the loss of the alkyne triplet at $\delta 2.53 \mathrm{ppm}$. Subsequent thiol-ene click provided the final dendrimer 6 with thirty amine functions in moderate yield. All the dendrimers and monomers were fully characterized using NMR spectroscopy, IR, and MALDI-TOF mass spectrometry. The MALDI-TOF results for all the macro- molecules showed strong signals corresponding to their expected molecular weights.

Dendrimers have been increasingly used for the delivery of drugs and genetic materials. ${ }^{51-58}$ To show that the present polyamine dendrimers can be useful in biological systems, they must undergo comprehensive biological studies, including measurements of cytotoxicity in different cell types. In the

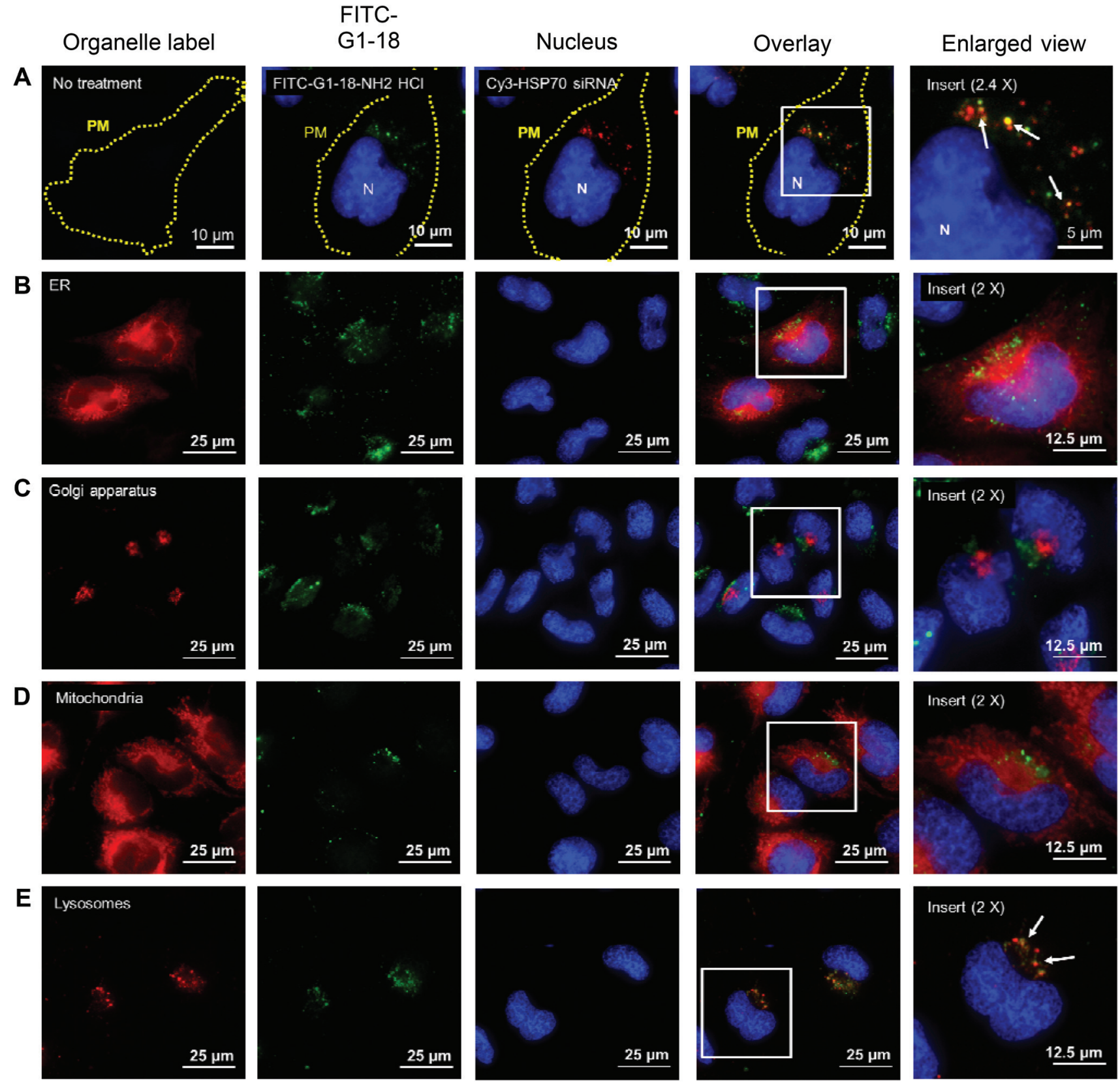

Fig. 3 Intracellular localization of FITC-labeled dendrimer 16 (FITC-G1-18) in U251N human glioblastoma cells. (A) Fluorescence micrographs of U251N cells transfected with Cy3-labeled anti-HSP70 siRNA using 16 for $24 \mathrm{~h}$. Insert shows colocalization of fluorescent signals from the siRNA (red) and the dendrimers (green). Background fluorescence is non-detectable. (PM = plasma membrane; $\mathrm{N}=$ nucleus). (B) Fluorescence micrographs of U251N cells exposed to 16 for $24 \mathrm{~h}$ and transduced with Cell Light endoplasmic reticulum-RFP. (C) Fluorescence micrographs of U251N cells exposed to 16 for $24 \mathrm{~h}$ and transduced with Cell Light Golgi-RFP. (D) Fluorescence micrographs of U251N cells exposed to 16 for $24 \mathrm{~h}$ and labeled with MitoTracker Deep Red for mitochondria. (E) Fluorescence micrographs of U251N cells exposed to 16 for $24 \mathrm{~h}$ and labeled with LysoTracker Red for lysosomes. 
present study, dendrimers G0 1-2 and G1 3-6, harboring 4, 6, 12,18 , and 30 surface amine groups respectively, were screened for effects on mitochondria metabolic activity (MTT) in three different human cell types: U251N human glioblastoma, MCF-7 breast carcinoma, and HepG2 liver adenocarcinoma cells (see ESI Fig. S51†). Significant cytotoxic effects were observed at micromolar concentrations, and dendrimers with more polyamine groups were more disruptive, as expected. The cytotoxic effect of the dendrimers was further assessed by cell counting in U251N cells treated with dendrimers with the highest number of functional groups G1-3 (12$\left.\mathrm{NH}_{2}\right)$, G1-4 (18- $\left.\mathrm{NH}_{2}\right)$ and G1-5 $\left(30-\mathrm{NH}_{2}\right)$ (see ESI Fig. S52 $\dagger$ ). Due to their high number of terminal groups and their relatively low cytotoxicity (up to $1 \mu \mathrm{M}$ ), dendrimers 3 and $\mathbf{4}$ were then further investigated as transfection agents.
Because the positively charged polyamines can interact with the negatively charged phosphate backbone of DNA and siRNA, these dendrimers have been used to induce gene overexpression by enhancing plasmid DNA internalization and knockdown of various genes by facilitating siRNA delivery. We investigated if polyamines $\mathbf{3}$ and $\mathbf{4}$ can effectively transport plasmid DNA inside cells. To show this, we used a plasmid encoding enhanced green fluorescent protein (eGFP, Fig. 3). Fluorescence micrographs of transfected cells showed that the eGFP signal can be easily detected following the delivery of eGFP plasmids using either $\mathbf{3}$ or $\mathbf{4}$, indicating successful transfections (transfection efficiencies were between $10.3 \%$ and $7.1 \%$, respectively) (Fig. 2A-C). Although the results suggest that the polyamines are not superior to the commercial comparator Lipofectamine $2000 \AA(37.6 \%)$ in terms of transfection
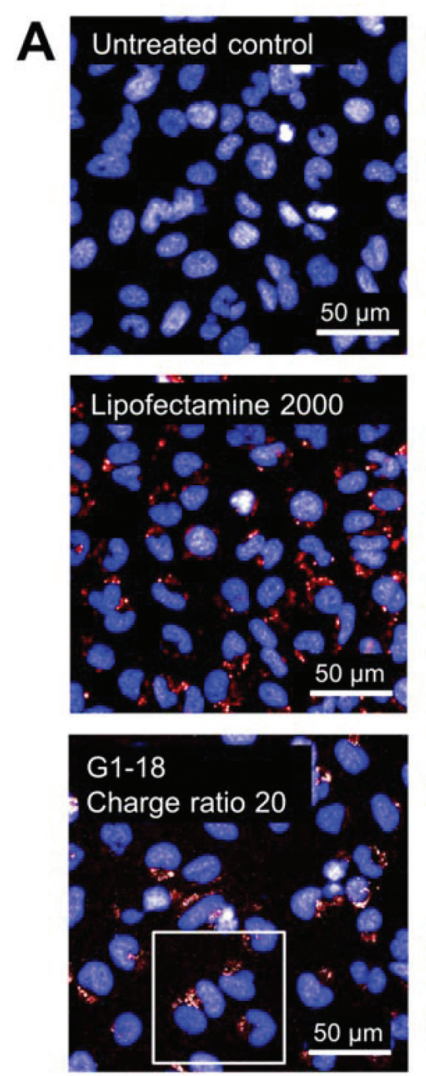
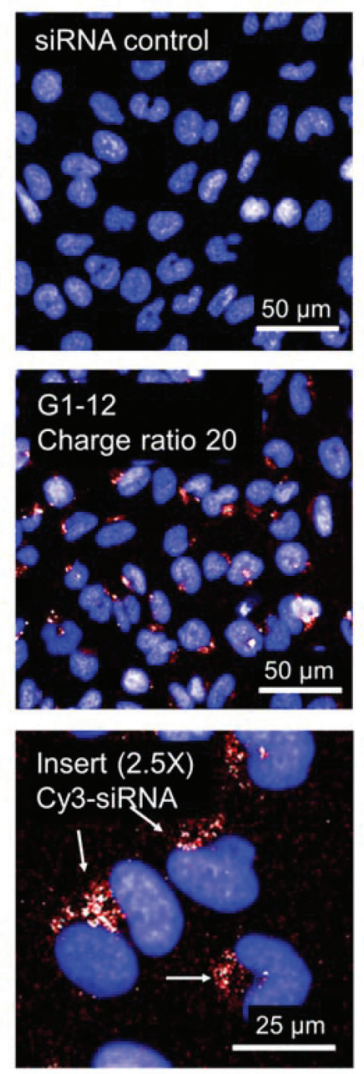
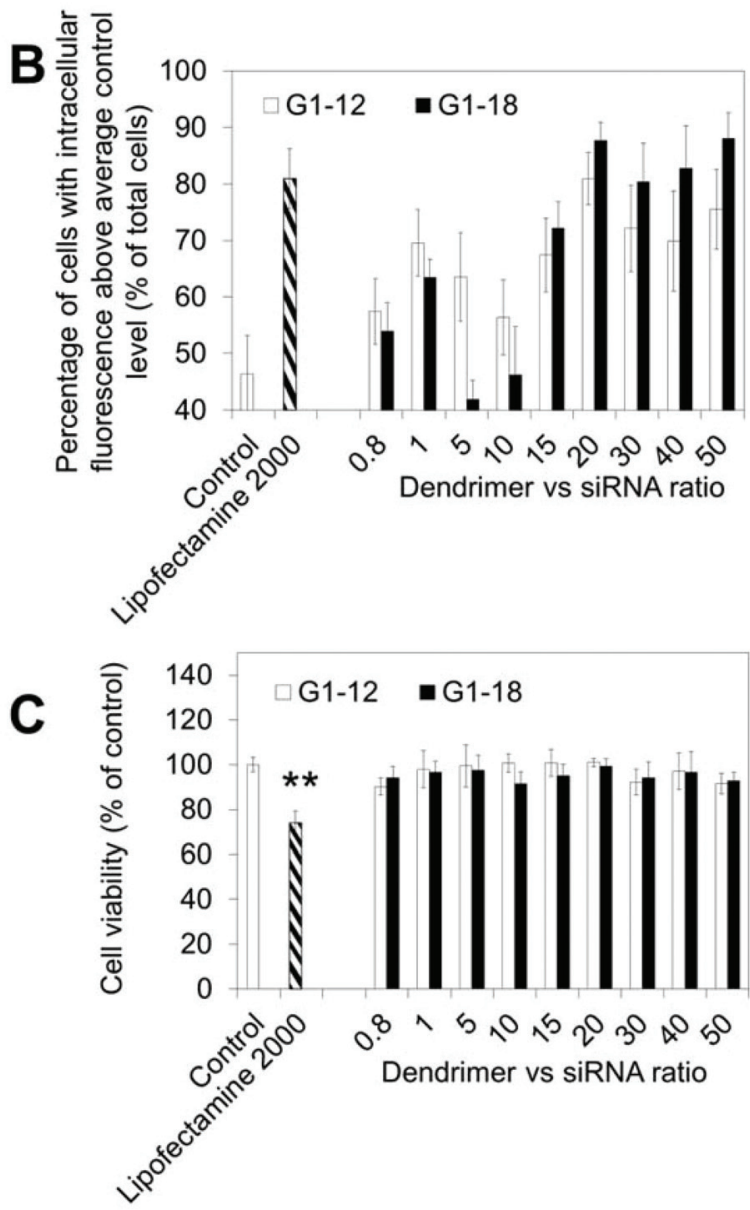

Fig. 4 Delivery of Cy3-labeled anti-HSP70 siRNA in U251N glioblastoma cells. (A) Fluorescence micrographs of human U251N glioblastoma cells transfected with Cy3-labeled anti-HSP70 siRNA (10 nM) for $24 \mathrm{~h}$ in serum deprived media, using the dendrimers 3 (G1-12) and 4 (G1-18). Red fluorescence signal from the Cy3-labeled siRNA is shown inside cells. Lipofectamine $2000 \AA$ was included as a commercially available comparator. No significant Cy3 fluorescence is detected in untreated and siRNA only controls. (B) Percentage of cells transfected with Cy3-labeled anti-HSP70 siRNA (10 nM) for $24 \mathrm{~h}$ in serum deprived media, following transfection using 3 and 4 at increasing charge ratios between dendrimer and siRNA. Lipofectamine $2000 \circledast(0.5 \mu \mathrm{L}$ per $100 \mu \mathrm{L})$ was included as a commercially available comparator. Transfection efficiencies were quantified by calculating the proportion of total cells which displayed intracellular red fluorescence intensities above the average untreated control levels. Shown are average percentage values \pm SEM from three independent experiments. (C) Cell viability following transfection of Cy3-labeled anti-HSP70 siRNA (10 $\mathrm{nM})$ for $24 \mathrm{~h}$ in serum deprived media, using 3 and 4 as in (B). Lipofectamine $2000 \circledast(0.5 \mu \mathrm{L}$ per $100 \mu \mathrm{L})$ was included as a commercially available comparator. Cell viability was measured by counting the number of Hoechst 33342 -labeled nuclei. Shown are average percentage values \pm SEM as compared to untreated controls from three independent experiments. $(* * p<0.001)$. 
efficiency, they were much less toxic. This would make polyamines advantageous for biological experiments where cytotoxicity imposes limitations (Fig. 2D).

To investigate the cellular uptake of the present polyamine constructs, 4 was fluorescently labeled with a single molecule of fluorescein isothiocyanate (FITC) to yield dendrimer 16 (see ESI Scheme S1 $\dagger$ ). Similarly to a recent study by Albertazzi et al. ${ }^{59}$ we then investigated if the FITC-labeled polyamine $\mathbf{1 6}$ was easily transported into cells without major loss of plasma membrane integrity and morphological disruptions. To this end we treated human glioblastoma U251N cells with the fluorescently labeled polyamine 16 to reveal their intracellular location (Fig. 3). The delivery of Cy3-labeled HSP70 siRNA using fluorescent 16 showed that both entities localized in discreet subcellular locations in the perinuclear region. We used organelle-specific reagents to label the endoplasmic reticulum
(ER) and the Golgi apparatus, and fluorescent vital dyes to label the mitochondria and lysosomes. Subsequent investigations using organelle-specific labels revealed that the intracellular localization of the FITC-labeled dendrimer was strongly associated with that of RFP-labeled lysosomes.

We then investigated if siRNA can be effectively delivered using polyamine dendrimers. A Cy3-labeled anti-HSP70 siRNA was employed to detect cells which received siRNAs following transfection. Our results showed that both the $\mathbf{3}$ and $\mathbf{4}$ polyamines can successfully deliver siRNA into human cells, with transfection efficiency comparable to that of Lipofectamine $2000 \AA$ (Fig. 4B). Measurements of cell viability following transfection showed that the polyamines are less cytotoxic than Lipofectamine $2000 \AA$, and thus are preferable for biological applications (Fig. 4C). Western blots (Fig. S55†) also confirmed the lower level of protein expression.
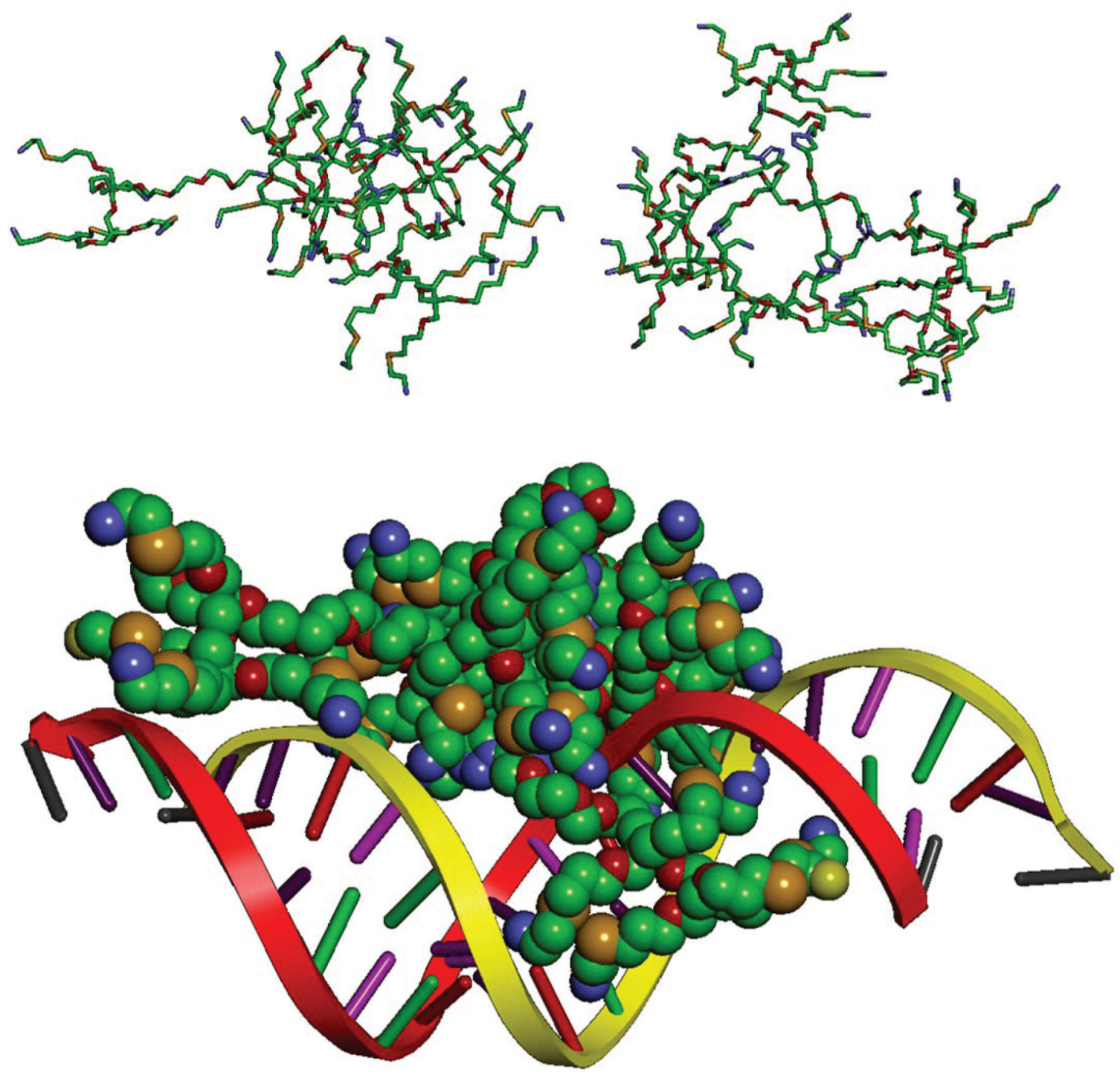

Fig. 5 Partially extended (top left, 30 ns) and folded (top right, 45 ns) conformations of dendrimer 5 obtained from the MD simulations. For the MD simulation, the 21 bp SiRNA GL3 Firefly Luciferase was used. 
We then measured the cell viability during the transfections using the mitochondria metabolic (MTT) activity of HEK 293 human embryonic kidney cells and U251N human glioblastoma cells in response to transfection of both eGFP plasmid DNA (pDNA) and heat-shock protein 70 (HSP70) small interfering RNA (siRNA), respectively, delivered with G1-12 (3) and G1-18 (4) dendrimers at different charge ratios for $24 \mathrm{~h}$ (Fig. S56 $\dagger$ ). The data clearly showed that our low generation cationic polyamine dendrimers $\mathbf{3}$ and $\mathbf{4}$ showed comparable behavior to that of Lipofectamine $2000 \AA$ taken as control.

In order to further understand the apparent lower transfection or knocking down ability (although after only $24 \mathrm{~h}$ ) of our low generation polycationic amine-ending dendrimers, we investigated their relative size and flexibility by molecular modeling. For this, we used dendrimer $\mathbf{5}$ as intermediate size architecture to better rely our data with those of usual larger PAMAM and other polyamine dendrimers described in the literature. $^{33}$ Based on previous observations from PAMAMrelated dendrimers, it may be expected that the highly flexible polyamine dendrimers with low generation would form extremely stable polyplexes and that could be argued as being the main reason for the low degree of efficacy for both types of nucleic acids when compared to the very large liposomal commercial transfectant Lipofectamine $2000 \AA$.

During the simulation in water, dendrimer 5 rapidly folds and does not stay extended in solution (even if this folding is quite dynamic due to repulsion between the surface charges). Two different complexes with siRNA were obtained. Starting from the equilibrated/folded dendrimer in one case or from the extended dendrimer (pre-equilibration) in the other, and placing the dendrimers in close contact with the siRNA provided two very similar complexes. The two different complexes were further immersed in a simulation box containing explicit water molecules and the necessary numbers of $\mathrm{Na}^{+}$ions for charge neutralization of the system were added. MD simulations lasted for $30 \mathrm{~ns}$ for the extended and $45 \mathrm{~ns}$ for the folded case, in which case both systems behave in the same way. Dendrimer 5 did not stay perfectly extended during binding (even in the case where it starts from a perfectly extended configuration), but it is flexible and it tends to "embrace/hug" siRNA to enhance binding. The fact that both systems are almost indistinguishable during the MD simulations demonstrates that the result (the behavior of 5 during siRNA binding) is not dependent on the initial conformation chosen for the dendrimer in the creation of the complex. The initially folded one results in only slightly more "hugging" siRNA, while the initially extended one assumes a slightly more folded configuration during binding (Fig. 5).

It thus became clear from the above dynamic modeling that the low generation dendrimers described in this study are rapidly "moving" and changing position along the anionic charge of the DNA molecules. Hence, they do not seem to form too highly stable polyplexes that can be argued for the lower transfection ability. Rather, it can be anticipated that their smaller size may necessitate a longer reaction time or even using extended side-chains. Work is now in progress to answer these questions.

\section{Conclusions}

The successful delivery of both plasmid DNA and siRNA in human cells indicates that the present low generation polyamine dendrimers can be promising delivery systems for research and therapeutic purposes. The delivery of anti-HSP70 siRNA in glioblastoma, for instance, can significantly reduce HSP70 mRNA levels and sensitize cancer cells to chemotherapeutic agents. ${ }^{60}$ Although commercial transfection agents such as Lipofectamine $2000 \AA$, HiPerFect ${ }^{\circledR}$, or Superfect ${ }^{\circledR}$ have high efficiencies, it is at the cost of reduced cell viability. Collectively, the present polyamine dendrimers can be synthesized through innovative, economical and efficient steps, and can successfully deliver both plasmid DNA and siRNA in human cells with minimal cytotoxicity. Such dendrimers could be particularly advantageous to knock down key pathways in cancer stem cells. ${ }^{61}$ The high flexibility and biocompatibility of the above TEG-based polyamine dendrimers may account for their valued efficacy. Indeed, as shown in Fig. 5, molecular modeling of one of the relaxed conformers of dendrimer 5 (G1-30 $\mathrm{NH}_{2}$ ), wherein two of the amine pairs can span over a distance of $52 \AA$ may account for the dendrimer's conformational adaptation $^{62}$ to better reach the anionic phosphate groups on plasmid DNA and siRNA. The above data confirm that polycationic pegylated dendrimers of low generation (G1 here) hold great promise as nanocarriers for gene transfection. In addition, this work also shows that globular dendrimers of high generation may not represent optimal structures for siRNA complexation since they may have unnecessary high cation/phosphate ratios.

\section{Acknowledgements}

This work was supported by grants from the Natural Science and Engineering Research Council of Canada (NSERC) to D. M. and R. R. We are also grateful to Dr A. A. Arnold (Nanoqam) for his technical assistance.

\section{References}

1 E. Buhleier, W. Wehner and F. Vögtle, Synthesis, 1978, 155.

2 D. A. Tomalia, H. Baker, J. Dewald, M. Hall, G. Kallos, S. Martin, J. Roeck, J. Ryder and P. Smith, Polym. J., 1985, 17, 117.

3 G. R. Newkome, Z. Yao, G. R. Baker and V. K. Gupta, J. Org. Chem., 1985, 50, 2003.

4 S. Svenson and D. A. Tomalia, Adv. Drug Delivery Rev., 2005, 57, 2106.

5 C. Dufès, I. F. Uchegbu and A. G. Schätzlein, Adv. Drug Delivery Rev., 2005, 57, 2177. 
6 A. R. Menjoge, R. M. Kannan and D. A. Tomalia, Drug Discovery Today, 2010, 15, 171.

7 C. Deraedt, N. Pinaud and D. Astruc, J. Am. Chem. Soc., 2014, 136, 12092.

8 D. Appelhans, B. Klajnert-Maculewicz, A. Janaszewska, J. Lazniewska and B. Voit, Chem. Soc. Rev., 2015, 44, 3968.

9 R. M. Kannan, E. Nance, S. Kannan and D. A. Tomalia, Int. J. Med., 2014, 276, 579.

10 H. Liu, Y. Wang, M. Wang, J. Xiao and Y. Cheng, Biomaterials, 2014, 35, 5407.

11 Y.-B. Lim, C. E. Mays, Y. Kim, W. B. Titlow and C. Ryou, Biomaterials, 2010, 31, 2025.

12 (a) A. Lakshminarayanan, B. U. Reddy, N. Raghav, V. K. Ravi, A. Kumar, P. K. Maiti, A. K. Sood, N. Jayaraman and S. Das, Nanoscale, 2015, 7, 16921; (b) S. Jain, A. Kaur, R. Puri, P. Utreja, A. Jain, M. Bhide, R. Ratnam, V. Singh, A. S. Patil, N. Jayaramanc, G. Kaushik, S. Yadav and K. L. Khanduja, Eur. J. Med. Chem., 2010, 45, 4997.

13 (a) T. Gonzalo, M. I. Clemente, L. Chonco, N. Weber, L. Díaz, M. J. Serramía, R. Gras, P. Ortega, F. J. de la Mata, R. Gómez, L. López, M. A. Muñoz-Fernández and J. L. Jiménez, ChemMedChem, 2010, 5, 921; (b) V. Briz, D. Sepulveda-Crespo, A. R. Diniz, P. Borrego, B. Rodes, F. J. de la Mata, R. Gómez, N. Taveira and M. A. MuñozFernández, Nanoscale, 2015, 7, 14449.

14 (a) D. Shcharbin, V. Dzmitruk, A. Shakhbazau, N. Goncharova, I. Seviaryn, S. Kosmacheva, M. Potapnev, E. Pedziwiatr-Werbicka, M. Bryszewska, M. Talabaev, A. Chernov, V. Kulchitsky, A.-M. Caminade and J.-P. Majoral, Pharmaceutics, 2011, 3, 458; (b) M. Ferenc, E. Pedziwiatr-Werbicka, K. Nowak, B. Klajnert, J.-P. Majoral and M. Bryszewska, Molecules, 2013, 18, 4451.

15 (a) X. Liu, P. Rocchi and L. Peng, New J. Chem., 2012, 36, 256; (b) C. Liu, X. Liu, P. Rocchi, F. Qu, J. L. Iovanna and L. Peng, Bioconjugate Chem., 2014, 25, 521; (c) X. Liu, J. Zhou, T. Yu, C. Chen, Q. Cheng, K. Sengupta, Y. Huang, H. Li, C. Liu, Y. Wang, P. Posocco, M. Wang, Q. Cui, S. Giorgio, M. Fermeglia, F. Qu, S. Prici, Y. Shi, Z. Liang, P. Rocchi, J. J. Rossi and L. Peng, Angew. Chem., Int. Ed., 2014, 53, 11822.

16 P. Xu, S.-Y. Li, Q. Li, J. Ren, E. A. Van Kirk, W. J. Murdoch, M. Radosz and Y. Shen, Biotechnol. Bioeng., 2006, 95, 893.

17 J. C. Roberts, M. K. Bhalgat and R. T. Zera, J. Biomed. Mater. Res., 1996, 30, 53.

18 S. P. Mukherjee and H. J. Byrne, Nanomedicine, 2013, 9, 202.

19 R. B. Kolhatkar, K. M. Kitchens, P. W. Swaan and H. Ghandehari, Bioconjugate Chem., 2007, 18, 2054.

20 B. Ziemba, G. Matuszko, D. Appelhans, B. Voit, M. Bryszewska and B. Klajnert, Biopolymers, 2012, 97, 642.

21 S. Wen, F. Zheng, M. Shen and X. Shi, J. Appl. Polym. Sci., 2013, 128, 3807.

22 R. Jevprasesphant, J. Penny, R. Jalal, D. Attwood, N. B. McKeown and A. D'Emanuele, Int. J. Pharm., 2003, 252, 263.
23 S. Zhu, M. Hong, G. Tang, L. Qian, J. Lin, Y. Jiang and Y. Pei, Biomaterials, 2010, 31, 1360.

24 H. Yang, S. Lopina, L. DiPersio and S. Schmidt, J. Mater. Sci.: Mater. Med., 2008, 19, 1991.

25 J. M. Harris and R. B. Chess, Nat. Rev. Drug Discovery, 2003, $2,214$.

26 L. M. Kaminskas, B. J. Boyd, P. Karellas, G. Y. Krippner, R. Lessene, B. Kelly and C. J. H. Porter, Mol. Pharm., 2008, $5,449$.

27 M. V. Walter and M. Malkoch, Chem. Soc. Rev., 2012, 41, 4593.

28 R. Sharma, I. Zhang, L. Abbassi, R. Rej, D. Maysinger and R. Roy, Polym. Chem., 2015, 6, 1436.

29 K. L. Killops, L. M. Campos and C. J. Hawker, J. Am. Chem. Soc., 2008, 130, 5062.

30 A. Lee, J. Chin, O. K. Park, H. Chung, J. W. Kim, S.-Y. Yoona and K. Park, Chem. Commun., 2013, 49, 5969.

31 J. Mackeviča, P. Ostrovskis, H. Leffler, U. J. Nilsson, V. Rudovica, A. Viksna, S. Belyakov and M. Turksa, Arkivoc, 2014, iii, 90.

32 G. M. Pavan, Chem. Med. Chem., 2014, 9, 2623.

33 G. M. Pavan, L. Albertazzi and A. Danani, J. Phys. Chem. B, 2010, 114, 2667.

34 D. A. Case, T. A. Darden, T. E. Cheatham III, C. L. Simmerling, J. Wang, R. E. Duke, R. Luo, R. C. Walker, W. Zhang, K. M. Merz, B. Roberts, S. Hayik, A. Roitberg, G. Seabra, J. Swails, A. W. Goetz, I. Kolossvary, K. F. Wong, F. Paesani, J. Vanicek, R. M. Wolf, J. Liu, X. Wu, S. Brozell, T. Steinbrecher, H. Gohlke, Q. Cai, X. Ye, J. Wang, M.-J. Hsieh, G. Cui, D. R. Roe, D. H. Mathews, M. G. Seetin, R. Salomon-Ferrer, C. Sangui, V. Babin, T. Luchko, S. Gusarov, A. Kovalenko and P. A. Kollman, AMBER 12, University of California, San Francisco, 2012.

35 J. Wang, R. M. Wolf, J. W. Caldwell, P. A. Kollman and D. A. Case, J. Comput. Chem., 2004, 25, 1157.

36 W. L. Jorgensen, J. Chandrasekhar, J. D. Madura, R. W. Impey and M. L. Klein, J. Chem. Phys., 1983, 79, 926.

37 T. Darden, D. York and L. Pedersen, J. Chem. Phys., 1993, 98, 10089.

38 V. Krautler, W. F. van Gunsteren and P. H. Hunenberger, J. Comput. Chem., 2001, 22, 501.

39 V. V. Rostovtsev, L. G. Green, V. V. Fokin and K. B. Sharpless, Angew. Chem., Int. Ed., 2002, 41, 2596.

40 P. Wu, A. K. Feldman, A. K. Nugent, C. J. Hawker, A. Scheel, B. Voit, J. Pyun, J. M. J. Fréchet, K. B. Sharpless and V. V. Fokin, Angew. Chem., Int. Ed., 2004, 43, 3928.

41 C. E. Hoyle and C. N. Bowman, Angew. Chem., Int. Ed., 2010, 49, 1540.

42 M. J. Kade, D. J. Burke and C. J. Hawker, J. Polym. Sci., Part A: Polym. Chem., 2010, 48, 743.

43 A. B. Lowe, Polym. Chem., 2010, 1, 17.

44 R. Sharma, N. Kottari, Y. M. Chabre, L. Abbassi, T. C. Shiao and R. Roy, Chem. Commun., 2014, 50, 13300.

45 J. E. Moses and A. D. Moorhouse, Chem. Soc. Rev., 2007, 36, 1249. 
46 Y. Kim, A. M. Klutz and K. A. Jacobson, Bioconjugate Chem., 2008, 19, 1660.

47 R. Sharma, K. Naresh, Y. M. Chabre, R. Rej, N. K. Saadeh and R. Roy, Polym. Chem., 2014, 5, 4321.

48 Y. Wang, W. Kong, Y. Song, Y. Duan, L. Wang, G. Steinhoff, D. Kong and Y. Yu, Biomacromolecules, 2009, 10, 617.

49 Y. Zhang, C. Zhou, K. J. Kwak, X. Wang, B. Yung, L. J. Lee, et al., Pharm. Res., 2012, 29, 1627.

50 H. Rajaram, M. K. Palanivelu, T. V. Arumugam, V. M. Rao, P. N. Shaw, R. P. McGeary and B. P. Ross, Bioorg. Med. Chem. Lett., 2014, 24, 4523.

51 S. Boridy, G. M. Soliman and D. Maysinger, Nanomedicine, 2012, 7, 1149.

52 D. A. Tomalia, L. A. Reyna and S. Svenson, Biochem. Soc. Trans., 2007, 35, 61.

53 D. W. Pack, A. S. Hoffman, S. Pun and P. S. Stayton, Nat. Rev. Drug Discovery, 2005, 4, 581.

54 J. Zhao and S.-S. Feng, Nanomedicine, 2015, 10, 2199.

55 S. Biswas and V. Torchilin, Pharmaceuticals, 2013, 6, 161.
56 C. A. Hong, A. A. Eltoukhy, H. Lee, R. Langer, D. G. Anderson and Y. S. Nam, Angew. Chem., Int. Ed., 2015, 54, 6740 .

57 D. Maysinger, D. Gröger, A. Lake, K. Licha, M. Weinhart, P. K.-Y. Chang, R. Mulvey, R. Haag and R. A. McKinney, Biomacromolecules, 2015, 16, 3073.

58 I. N. Kurniasih, J. Keilitz and R. Haag, Chem. Soc. Rev., 2015, 44, 4145.

59 L. Albertazzi, B. Storti, L. Marchetti and F. Beltram, J. Am. Chem. Soc., 2010, 132, 18158.

60 M. Matokanovic, K. Barisic, J. Filipovic-Grcic and D. Maysinger, Eur. J. Pharm. Sci., 2013, 50, 149.

61 N. Takebe, L. Miele, P. J. Harris, W. Jeong, H. Bando, M. Kahn, S. X. Yang and S. P. Ivy, Nat. Rev. Clin. Oncol., 2015, 12, 445 .

62 A.-M. Caminade, S. Fruchon, C. O. Turrin, M. Poupot, A. Ouali, A. Maraval, M. Garzoni, M. Maly, V. Furer, V. Kovalenko, J.-P. Majoral, G. M. Pavan and R. Poupot, Nat. Commun., 2015, 6, 7722. 